\title{
Precipitation on the lee side of the Vosges Mountains: Multi-instrumental study of one case from the COPS campaign
}

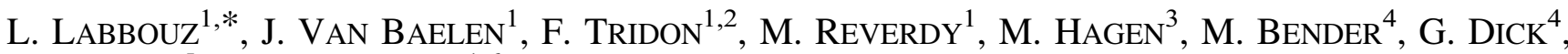 \\ T. GORGAS ${ }^{5}$ and C. PLANCHE ${ }^{1,6}$
}

${ }^{1}$ Laboratoire de Météorologie Physique, CNRS UMR 6016, Clermont Université, Université Blaise Pascal and CNRS, Clermont-Ferrand, France

${ }^{2}$ Currently at Earth Observation Sciences, Department of Physics and Astronomy, University of Leicester, Leicester, United Kingdom

${ }^{3}$ Institut für Physik der Atmosphäre, Deutsches Zentrum für Luft- und Raumfahrt, Oberpfaffenhofen, Germany

${ }^{4} \mathrm{GPS} /$ Galileo Earth Observation, German Research Centre for Geosciences, Potsdam, Germany

${ }^{5}$ Department of Meteorology and Geophysics, University of Vienna, Austria

${ }^{6}$ Currently at School of Earth and Environment, Institute for Climate and Atmospheric Science, University of Leeds, Leeds, United Kingdom

(Manuscript received July 12, 2012; in revised form December 21, 2012; accepted January 16, 2013)

\begin{abstract}
In this article, we focus on one case study from the Convective and Orographically-induced Precipitation Study (COPS), which took place in north-eastern France and south-western Germany during the summer of 2007 , in a low mountain area. We investigate lee side precipitation due to shallow and deep convection during one Intensive Observation Period (IOP) of COPS which have been well documented by all the instruments. For that aim, we use a set of observations from radars, radiosoundings, satellite, and a network of Global Positioning System (GPS) receivers, as well as meteorological analyses and dedicated model simulation results. The combination of these measurements with GPS tomography results suggests the role of low level water vapour accumulation and convergence as a precursor to the convective initiation. The origin of this moistening and wind convergence seems to be linked to a slight change in the wind direction in the north-west part of the COPS domain. Using a high resolution X band radar, we also describe how small scale orography affects the precipitation locations, and we show the role of hills near the mouths of the valleys in convective enhancement. This observation is confirmed by model simulation showing that convection is no longer enhanced when the hills are suppressed. The further intensification of one convective cell over the Rhine Valley, which is climatologically frequent, is also discussed.
\end{abstract}

Keywords: COPS, convection, GPS meteorology.

\section{Introduction}

The study of orographic precipitation is of major importance because mountainous regions are very sensitive areas often prone to high risk of flooding. Moreover, because of its complexity, such orographic precipitation is difficult to predict quantitatively. Over time, different research campaigns have been designed to improve the knowledge of precipitation mechanisms, focussing on both convection initiation mechanisms and microphysics processes. Among others, we can cite the Mesoscale Alpine Program (MAP) in September-November 1999, which focussed on precipitation over high mountains (BOUGEAUlt et al., 2001; RotUNNO and Houze, 2007), the International $\mathrm{H}_{2} \mathrm{O}$ Project (IHOP) which studied the links between 3D water vapour field and convective processes over the USA Southern Great Plains, in May-June 2002 (WECKWERTH et al., 2004) and the

${ }^{*}$ Corresponding author: Laurent Labbouz, LaMP, 24 av. des Landais, BP80026, 63171 Aubière Cedex, France,

e-mail: 1.labbouz@opgc.univ-bpclermont.fr, 1.labbouz@gmail.com
Convective Storm Initiation Project (CSIP) in summers 2004 and 2005, which took place over the hills of southern England, under a strong maritime influence (BROWNING et al., 2007).

The present study is made in the framework of the Convective and Orographically-induced Precipitation Study (COPS) which took place during the summer 2007 in the low mountain area between south-western Germany and north-eastern France (WULFMEYER et al., 2008, 2011). The COPS domain stretched over a complex terrain including the Vosges Mountains, the Rhine Valley, The Black Forest and the Swabian Jura (Fig. 1). Statistics of convection initiation during the COPS campaign are given by AOSHIMA et al. (2008), and a climatology of convective events (initiation and enhancement) over the COPS domain is analysed in WECKWERTH et al. (2011). These studies show that convective initiation is more common over the mountain regions (the Black Forest and to a minor extent the Vosges Mountains) than in the Rhine Valley, while a high frequency of convection enhancement events is observed over the Rhine Valley. 


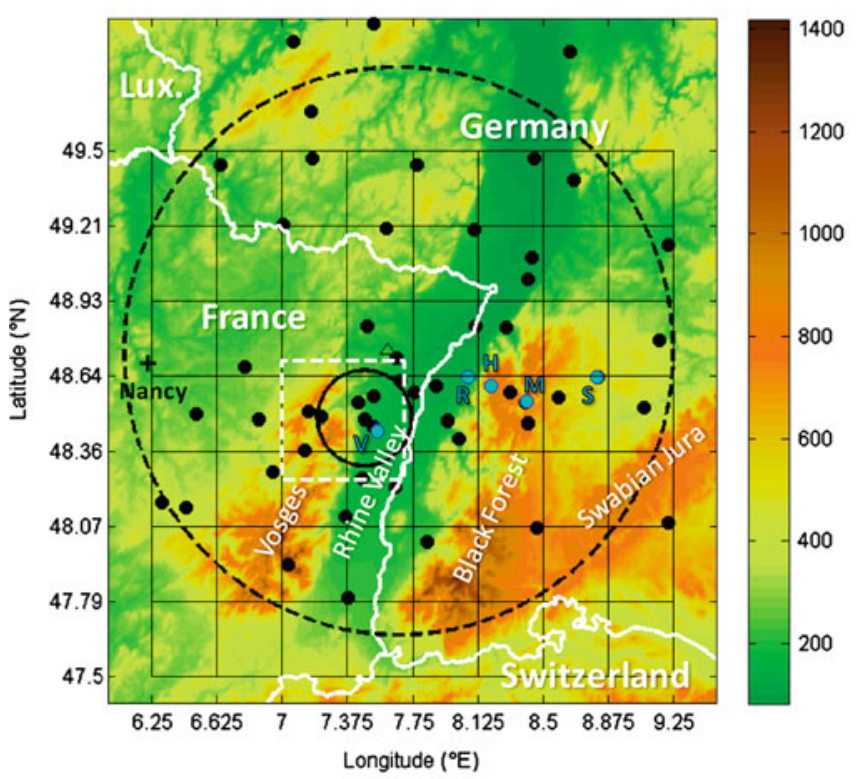

(a)

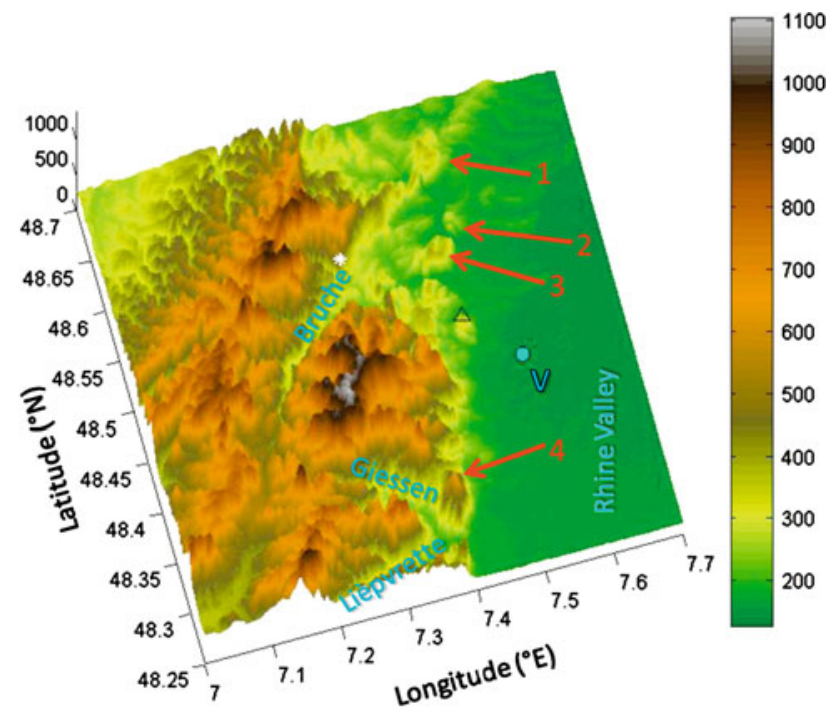

(b)

Figure 1: (a): The COPS domain between France and Germany. The five supersites, including supersite V, are marked by blue dots with black edging. Black dots indicate GPS stations (note that each supersite has also one GPS station collocated or nearly collocated). The black solid circle shows the $\mathrm{X}$ band radar maximum range (20 km radius), and the dashed circle is the POLDIRAD maximum range (120 km radius). The POLDIRAD location is given by the black edged triangle. The black grid indicates the pixels used for tomographic inversion. The black cross indicates the Nancy synoptic radiosounding station. Colour scale indicates the topography (in meters). White solid lines are for country borders, and "Lux." stands for Luxembourg. The principal area of interest for this study is inside the dashed white rectangle. (b): 3D representation of the area inside the dashed white rectangle in (a). The blue names indicate the main valleys in this area of the Vosges Mountains. The red arrows and corresponding numbers (1-4) show four hills mentioned in the text, which are also highlighted in Fig. 6a (hills no. 1-3) and in Fig. 8a (hill no. 4) to help for cross-referencing the figures. The white star marks the first convective initiation location (see Fig. 6a, and section 3.2.1). For more clarity in this zoom, only the marker for supersite V (blue dot) and for the LaMP X band radar location (black triangle, not seen in (a) because nearly collocated with a GPS receiver) are kept. The topography (in meters) is given by the colour scale (and z-axis).

The overall objective of COPS is to improve the Quantitative Precipitation Forecast skills of Numerical Weather Prediction models over a region of moderate topography. In that aim, the COPS campaign joined together scientists from the modelling and experimental communities for a three month international project. Within these three months, more instruments were available during July (especially in the French part of the COPS domain) especially during Intensive Observations Periods (IOPs). A large number of instruments were deployed during the campaign, mainly in five supersites (Fig. 1). We will focus here on data from supersite $\mathrm{V}$ and over the Vosges and the west part of the Rhine valley. The main data and techniques we used in our analyses are described in section 2 .

We focus our study on 18 July 2007, which corresponds to IOP9a. We selected this case because it exhibits interesting local lee side Convective Initiations (CI), quite well observed by numerous instruments available during this day. As mentioned in many earlier articles (see e.g. SMITH, 1979; RoE, 2005) precipitation over the lee side of mountains is generally weaker than over the crest / windward side ("rain shadow effect"). Likewise typical mechanisms of lee side precipitation are described in numerous articles, such as BANTA, 1990; HouZE, 1993; HAGEN et al., 2011 to name a few.

According to BANTA (1990) the splitting of the flow by a mountain which is not parallel or nearly parallel to the wind direction can produce convergence on the lee side of the mountain. This convergence can trigger lee side convection. THIELEN and GADIAN (1996) present high-resolution simulations of a low mountain area and show that the first convective outbreak occurs preferentially on the lee side, even when the sun heated slopes are the windward slopes. They suppose that an important perturbation of the flow, possibly including lee waves, favours lee side CI, while in their case, urban areas further impact CI (THIELEN and GADIAN, 1997). In their studies, they investigate different wind profiles in term of direction, but they do not test the influence of wind speed itself, and do not discuss the influence of the Froude number $F r=\frac{U}{N H}$ (with N the Brunt-Vaissala frequency, $\mathrm{U}$ the mean wind speed of the flow, and $\mathrm{H}$ the characteristic height of the mountain range). This number is widely used in hydrodynamics and known as a key parameter for flow interaction with an obstacle as it separates subcritical $(\mathrm{Fr}<1)$ from supercritical flow $(\mathrm{Fr}>1)$. Usually, when the Froude number is greater 
than unity the flow mainly crosses the obstacle and when it is lower than unity, the flow splits around the obstacle.

A discussion of the influence of the Froude number (and also its limitations) for $\mathrm{CI}$ is made by HAGEN et al. (2011). They use radar data and thus define CI from the beginning of precipitation (the C-band radar used does not detect clouds). They show that CI occurs on the lee side mainly when the Froude number is greater than 1 (corresponding to moderate to strong wind speed). However, they point out that the wind is not perpendicular to the crest and thus the interpretation of the Froude number has to be made carefully. A high Froude number in the COPS region corresponds to flows through the valleys and gaps, more than over the mountain chain itself. Hence, these complex mountain flows are prone to generate lee side convergence.

VAN BAELEN et al. (2011) show how the GPSretrieved water vapour field can improve the understanding of various convective conditions (lee side / ridge) during the COPS campaign. The aim of the present study is double. We first present some improvements which have been made in respect to VAN BAELEN et al. (2011). Indeed, we develop a new method to produce 2D Integrated Water Vapour (IWV) maps from GPS data at various altitudes, and henceforward use it for a better initialization of the tomographic inversion. Then, in the third section of this paper, we combine the improved GPS IWV and tomography results with a complete set of multi-instrumental observations to investigate in details convective initiation and enhancement during one specific case of lee side convection: the $18^{\text {th }}$ of July 2007 case (COPS IOP9a). In their work PLANCHE et al. (2013) specifically investigate the influence of the relief on the initiation of convective cells during three COPS cases (including IOP9a). Using the same simulation setup, we also complement our observational analysis by numerical model results to show the role of orography in the convective lifecycle.

\section{Data and methods}

\subsection{Vienna Enhanced Resolution Analysis}

Thanks to a European network of meteorological ground stations (which give hourly measurements of wind, pressure, temperature and humidity), the Vienna Enhanced Resolution Analysis, VERA (STEINACKER et al., 2000, 2006; BICA et al., 2007) provides continuous meteorological fields which are useful for GPS data processing (see section 2.3) and for synergetic use with other measurements (see section 3). VERA is a state-of-the-art tool for objective data analysis. Station data which are irregularly distributed are checked for both gross and systematic errors. Then they are interpolated to a regular grid using a so-called fingerprint method (BICA et al., 2005; STEINACKER et al., 2006), based only on physical a priori knowledge (model-independent) to take into account the role of orography in meteorological fields. Hence, VERA provides mean sea level pressure, potential temperature, equivalent potential temperature, and wind fields. The water vapour mixing ratio and the moisture flux divergence are then calculated as post-processing products.

The analysis results are given hourly at ground level with a $4 \mathrm{~km}$ resolution. The full VERA domain is quite large $(1664 \mathrm{~km} \times 1536 \mathrm{~km})$, but in this article we show the analysis in a smaller area, corresponding to the main region of interest, from $47.5^{\circ} \mathrm{N}$ to $49.0^{\circ} \mathrm{N}$ and from $6.5^{\circ} \mathrm{E}$ to $8.5^{\circ} \mathrm{E}$.

\subsection{Radars}

The observations of precipitating systems over the Vosges Mountains relevant to this work were performed mainly with two radars: the POLDIRAD radar and the LaMP X band radar (see Fig. 1 for location), which were specially deployed for the COPS campaign (HAGEN et al., 2011; WULFMEYER et al., 2011). Hereafter, the "precipitation" and "convection initiation" expressions will be used to refer to, respectively, "precipitation detected by one of the radars" and "the first radar echoes detected leading then to the formation of a convective cell".

The DLR POLDIRAD radar (SCHROTH et al., 1988) is a C-band Doppler and polarimetric radar. During the campaign, it provided Plan Position Indicator (PPI) scans every 10 minutes, at $1^{\circ}$ and $2^{\circ}$ elevation, up to a range of $120 \mathrm{~km}$, and Range Height Indicator (RHI) from about $0.2-1^{\circ}$ to $30-40^{\circ}$ elevation, at an azimuth of $110^{\circ}$ (which is toward the supersite R, see Fig. 1). The beam width is $1^{\circ}$ (both in azimuth and elevation) and the radial resolution is $300 \mathrm{~m}$. Because of excessive ground clutter at $1^{\circ}$ elevation, we prefer to use the $2^{\circ}$ PPI scan observations for this study. Although most of the ground clutter has been removed, some close range effects still remain.

The LaMP X band radar (VAN BAELEN et al., 2009) provides PPI scans under a fixed elevation of $5^{\circ}$ with a temporal resolution of 30 seconds and a spatial resolution of $60 \mathrm{~m}$ in range and $2^{\circ}$ in azimuth up to a range of $20 \mathrm{~km}$. Beyond ground clutter removal, the data processing also includes filtering of reflectivity peaks due to interferences, radar noise and eventual signal artefacts due to the shape of the antenna. Attenuation correction based on the HITSCHFELD and BORDAN (1954) method is performed using an iterative inter-calibration in the common volume of the radar with a nearby Micro Rain Radar (PETERs et al., 2005). The complete processing of the $\mathrm{X}$ band radar data is detailed in TRIDON (2011).

The wind profile at supersite $\mathrm{V}$ is measured by a boundary layer wind profiler system operated at $1280 \mathrm{MHz}$. The profiler is composed of five beams, one pointing vertically and the others towards four orthogonal directions inclined at $17^{\circ}$ off zenith. The wind component along each beam direction is deduced from the Doppler shift of the backscattered signal. The three 
wind components are then deduced from the five redundant radial velocities, with the assumption of no horizontal gradient of wind within the entire volume scanned by the radar. The profiler vertical resolution is $150 \mathrm{~m}$, and its time resolution is $6 \mathrm{~min}$.

\subsection{GPS data and tomography}

Although the first aim of GPS is precise positioning for navigation, the potential of GPS for Integrated Water Vapour (IWV) retrieval and even for tomography has been known for about twenty years (BEVIS et al., 1992). The effective use of GPS tomography for atmospheric studies is more recent but has been presented in numerous articles over the last decade, using various tomography techniques (FLORES et al., 2001; SEKO et al., 2004; BASTIN et al., 2005; BI et al., 2006; CHAMPOLLION et al., 2009; VAN BAELEN et al., 2011). In the framework of the campaign, the existing permanent GPS station network was complemented by additional temporary stations over the COPS domain with a higher density along a line across the Rhine Valley, connecting four of the five supersites. Fig. 1a shows the location of GPS stations providing data for the current case study. Thanks to this network the 3D water vapour field can be retrieved.

The refractive index of air is greater than unity and depends on meteorological parameters (THAYER, 1974), which means that the atmosphere delays electromagnetic waves such as the GPS microwave signals (ASKNE and NORDIUS, 1987; BEVIS et al., 1992). Hence, one can calculate precisely the atmospheric propagation delay along each satellite-antenna ray. These delays are called Slant Total Delays (STD), and in our work they have been directly estimated using the EPOS analysis software (BENDER et al., 2008). In the framework of COPS they have been validated by comparing with radiometer and model simulations (DENG et al., 2011), even if some problems remain at very low elevations where the STDs are often noisy. Thus, a cut-off angle of $7^{\circ}$ elevation was applied.

For water vapour retrieval and tomography, we need the Slant Integrated Water Vapour (SIWV) amount, i.e. the total amount of water vapour integrated along each ray path. These SIWV are calculated in a very standard way which is presented in the appendix. In the following sub-sections, we give a special care to the methods used to calculate IWV from SIWV, to produce 2D IWV maps and to initialize the tomographic inversion, because they have been recently developed and are thus different from those presented in VAN BAELEN et al. (2011).

\subsubsection{Integrated Water Vapour}

The IWV (i.e. the total amount of water vapour along the vertical direction) at each GPS station is needed for tomography initialization (see next section) and for the case study itself. There, an IWV is estimated from each single SIWV, using the Niell wet mapping function (NIELL, 1996). These individual IWVs are all different because they cross different parts of the atmosphere (satellites at different azimuths and elevations). In order to take that distribution into account, a reference position is associated to each of these IWVs. This reference position corresponds to the location where the path reaches an altitude such as the half of the water vapour is above it (usually around $2 \mathrm{~km}$ height). Hence, a set of IWV is available at different positions around each GPS station and a surface is fitted to these IWVs. The resulting IWV at the GPS station location is then estimated from the surface equation.

However, the water vapour density decreases with altitude and, thus, interpolation of IWV between GPS stations with substantial differences of altitude has to be done carefully. More precisely, in a mountainous terrain with stations positioned in the valleys and on the mountain tops, we cannot easily perform the IWV interpolation if there are not enough stations to resolve the slopes. The COPS GPS network corresponds to this situation. Therefore we need to take this altitude effect into account when generating 2D IWV maps. The IWVs must be normalized to a reference pressure (or altitude) level before being spatially interpolated. MORLAND and MÄTZLER (2007) propose an empirical method for climatological studies based on the exponential decrease of the water vapour density with altitude. They apply their method on six hours averaged GPS data but still observe some anomalies in case of high IWV horizontal gradients.

Here, we propose another simple method more adapted to the high temporal resolution GPS data we use. This method is based on the extrapolations of the measurements to a reference altitude (chosen as the $1000 \mathrm{hPa}$ level), using the European Centre for Medium-range Weather Forecast (ECMWF) RA-Interim Analysis (SIMONS et al., 2007; DEE et al., 2011). First, the IWV obtained from interpolated ERA-Interim data are calculated, for each GPS station and at every time step. Then, the coefficient $c$ is defined by:

$$
c=\frac{I W V_{G P S}}{I W V_{E C M W F-z}}
$$

with $I W V_{E C M W F-z}$ the IWV calculated from ECMWF analysis between GPS station height and $12 \mathrm{~km}$ height (which is not the highest ECMWF level but corresponds to the top of the grid used for tomography, see next section). And finally, the IWV extrapolated at the $1000 \mathrm{hPa}$ reference level are estimated:

$$
\mathrm{IWV}_{0}=\mathrm{IWV}_{\mathrm{GPS}}+\mathrm{c}\left(\mathrm{IWV}_{\mathrm{ECMWF}-0}-\mathrm{IWV}_{\mathrm{ECMWF}-\mathrm{z}}\right)
$$

where $I W V_{E C M W F-0}$ is the amount of water vapour integrated between the reference level and $12 \mathrm{~km}$ height. 2D water vapour maps are obtained by interpolation between all these $I W V_{0}$. 


\subsubsection{Tomography}

In the tomography method, the analysis domain above the GPS network is cut into boxes (usually called voxels, for volume pixels). The tomographic inversion retrieves the water vapour density (i.e. the mass of water vapour per cubic meter of air) inside each voxel using the SIWVs and the lengths of the corresponding rays within each voxels. The ray length within each voxel, which is a key parameter for the inversion, is calculated at the first order, i.e. with the approximation of a spherical Earth and neglecting the ray bending due to atmospheric refractivity gradients.

An a-priori water vapour field is needed to initialize the inversion with a 4D water vapour field at the spatial and temporal resolution of tomography. Such a dataset does not exist and thus the low resolution ERA-Interim data are used. These analyses are given with a horizontal resolution of $0.5^{\circ}$ in longitude and latitude, 21 vertical levels below $12 \mathrm{~km}$, and a temporal resolution of 6 hours (analyses are made four times a day, at 00:00, 06:00, 12:00 and 18:00 UTC). Although this resolution is very low compared to the expected tomography resolution, it has the merit to introduce realistic vertical structure in the field which is not the case with the standard theoretical exponential decay used in the previous version of the tomography (REVERDY, 2008, REVERDY et al., 2009; VAN BAELEN et al., 2011). Thus, the ECMWF analyses are interpolated first vertically and then horizontally (for each vertical layer) in order to obtain the necessary spatial resolution. Finally, a temporal linear interpolation is performed. We do not use any soundings, so that they could be used later for independent comparison with tomography results. Moreover, radiosoundings made during COPS are not uniformly distributed either in space or in time and the lack of radiosoundings around the COPS domain is problematic for interpolation.

To obtain an initialization consistent with the GPS data, we want ECMWF derived IWV to be the same as GPS derived IWV. In order to do this comparison, we estimate the mean coefficient $c$ (as defined in the previous section) in each pixel shown in Fig. 1, i.e. in each column of voxels. Then we scale the ECMWF data to the GPS, multiplying by $c$, and use them to initialize the tomography.

The tomographic routines themselves have already been presented in REVERDY (2008), REVERDY et al. (2009) and VAN BAELEN et al. (2011). They use damped weighted least squares to retrieve the $3 \mathrm{D}$ water vapour field from the SIWV. In the current study, the tomography is run with a temporal resolution of 5 minutes. Then, in order to reduce the jumps in GPS data mainly due to the change in the available satellite between time $t$ and $\mathrm{t}+5$ minutes, we use a 20 min sliding average window. The horizontal resolution is of about $30 \mathrm{~km}$, with $8 \times 7$ horizontal pixels (Fig. 1a), and there are 27 vertical levels, from mean sea level to $12 \mathrm{~km}$ above, with a thickness of $150-200 \mathrm{~m}$ in the low atmosphere (up to $3 \mathrm{~km}$ height), and then increasing with height. That moderate resolution is a compromise between the need of a sufficient resolution, and the limited number of available SIWV (increasing the number of voxels would result in an increase of the number of voxels without any ray crossing them). In the present study, some results obtained from higher resolution tomography are also presented (tomography with $16 \times 14$ pixels, i.e. about $15 \mathrm{~km}$ horizontal resolution). This allows finer scale analysis, but the results obtained have to be analysed carefully as the number of voxels poorly filled by STDs (or even empty) increases leading to possible artifacts in the tomography results.

\section{Case study: July $18^{\text {th }}, 2007$ (IOP9a)}

\subsection{Synoptic conditions}

On July $18^{\text {th }} 2007$, the COPS domain is in the transition area between a long-wave mid/upper level trough initially stretching south-westward from the central part of Scandinavia over the North Sea and the British Isles towards the Azores and a rather intense ridge covering northern Africa, the western and central parts of the Mediterranean Sea region as well as south-eastern Europe. This area is crossed by a quite strong south-westerly flow, with wind speed of about $15 \mathrm{~ms}^{-1}$ at $700 \mathrm{hPa}$ (Fig. 2b).

The associated surface pressure field has the same structure but with low pressure gradients over central Europe (Fig. 2a). A surface frontal zone separates hot and moist air in the southeast from cooler and more stable air to the northwest (Fig. 2c, d). This SW-NE orientated front, in the vicinity of the COPS region, is favourable for large scale lifting due to air-mass advection associated with strong temperature gradients which trigger lifting of the warmer air over the colder air. Moreover, according to the Deutscher Wetterdienst (DWD, German meteorological service) analysis charts a synoptic convergence line at ground level crosses the COPS domain at 18:00 UTC (Fig. 2d). Hence there is a moderate large scale forcing and a low level lifting is expected, which could favour convection initiation and enhancement.

Moreover, the radiosoundings at supersite $\mathrm{V}$ (on the lee side of the Vosges Mountains) give a Mixing Layer CAPE (BANTA, 1990) of about $750-800 \mathrm{~J} \mathrm{~kg}^{-1}$ both at 14:15 UTC and 17:15 UTC with respectively the Convective Condensation Level at $1350 \mathrm{~m}$ and $1500 \mathrm{~m}$, the Level of Free Convection at $1500 \mathrm{~m}$ and $1800 \mathrm{~m}$ and Equilibrium Level at about $9300 \mathrm{~m}$ for both radiosoundings (Fig. 3). The CIN is lower than $10 \mathrm{~J} \mathrm{~kg}^{-1}$. Hence, the thermodynamic conditions are favourable at least to shallow convection, with moderate CAPE and low $\mathrm{CIN}$, so that convection could initiate and enhance especially if the large scale forcing is supported by a more local forcing. The Nancy radiosounding at 12:00 UTC 

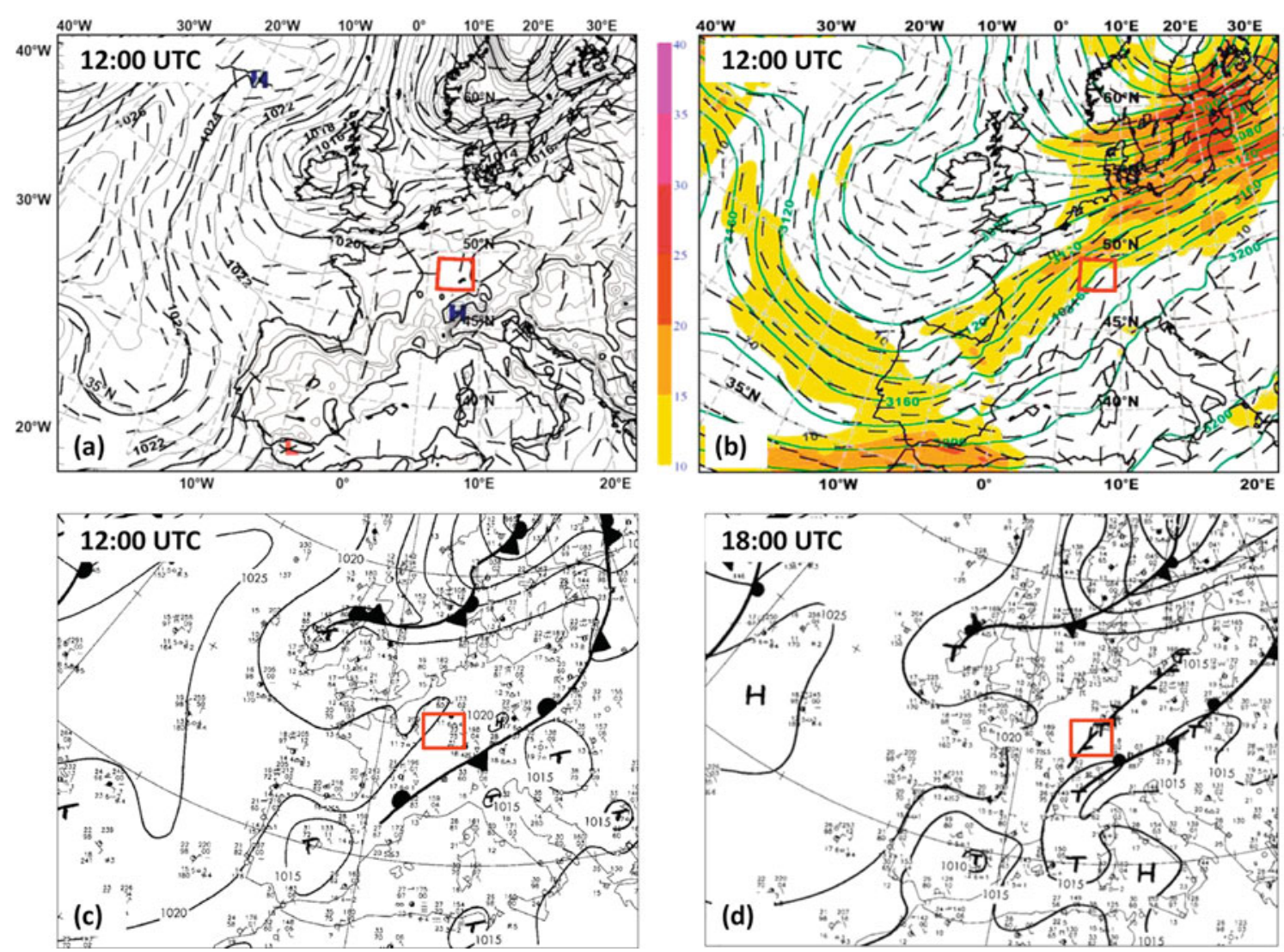

Figure 2: $(\mathrm{a}, \mathrm{b})$ : Surface AMSL pressure $(\mathrm{hPa})$ and wind direction at $10 \mathrm{~m}$ height (a) and geopotential height (in meters) and horizontal wind (barbs and colour scale, in $\mathrm{m} . \mathrm{s}^{-1}$ ) at $700 \mathrm{hPa}$ (b) from the European Centre for Medium-range Weather Forecast (ECMWF) Analyses on 18 July 2007 at 12:00 UTC. (c, d) : Deutscher Wetterdienst (DWD, German Meteorological Service) analyses charts showing surface fronts and wind convergence lines at 12:00 UTC (c) and 18:00 UTC (d). The red boxes (a-d) show the COPS domain.

(not shown) reveals a Froude number greater than unity above $600 \mathrm{~m}$, especially between $600 \mathrm{~m}$ and $1500 \mathrm{~m}$, indicating that the flow mainly crosses the mountains, and that no blocking situation is expected, either on the windward side of the Vosges or upstream (note that the Froude number in the lower layers of the atmosphere is not defined because the atmosphere is not stable but neutral / locally unstable). Thus, this flow is not expected to lead to convergence upstream on the west part of the Vosges Mountains, but could interact with the valley winds and lead to convergence near the ground or at higher altitudes, over the crest or on the lee side.

VERA wind and Moisture Flux Convergence (MFC) fields complete this overview of the synoptic conditions, making the link with the mesoscale and the local conditions (Fig. 4). We can first observe that during the period 14:00 UTC - 17:00 UTC, there is MFC over the Vosges crest and on the lee side, which contrast with moisture flux divergence in the Rhine valley and to a minor extent in the Black Forest (a more detailed analysis of VERA wind and MFC fields is given in the next section). As discussed for instance in BANACOS and SCHULTZ (2005) on a meso / synoptic scale and in KALTHOFF et al. (2009) on a more local point of view, this MFC can be an important trigger of convection. Hence, in the current case study, the observed moderate CAPE, low CIN, meso-scale MFC and moderate larger scale forcing generate a suitable context for convective initiation and enhancement.

\subsection{Local observations of precipitation, water vapour and wind}

\subsubsection{Observations of precipitating systems}

POLDIRAD (Fig. 5) observed some light showers (with maximum reflectivity of about $25 \mathrm{dBZ}$ ) on the west of the Vosges during the afternoon from about 15:30 UTC until the end of the day. These small non-convective cells seem to be advected rather than locally formed as they progress towards the north-east in agreement with the synoptic conditions (i.e. in our case the surface front in the north-west of the COPS domain) which are consistent with ECMWF wind analysis at $700 \mathrm{hPa}$ (Fig. 2a).

At 16:40 UTC a small cell initiates in the Bruche valley mouth (Fig. 5b) and develops quite rapidly with POLDIRAD maximum reflectivity reaching $40 \mathrm{dBZ}$ at 16:50 UTC and more than $55 \mathrm{dBZ}$ at 17:10 UTC (Fig. 5c). This initial reflectivity peak does not develop further and 10 minutes later the reflectivity decreases, with only very small areas of reflectivity greater than 

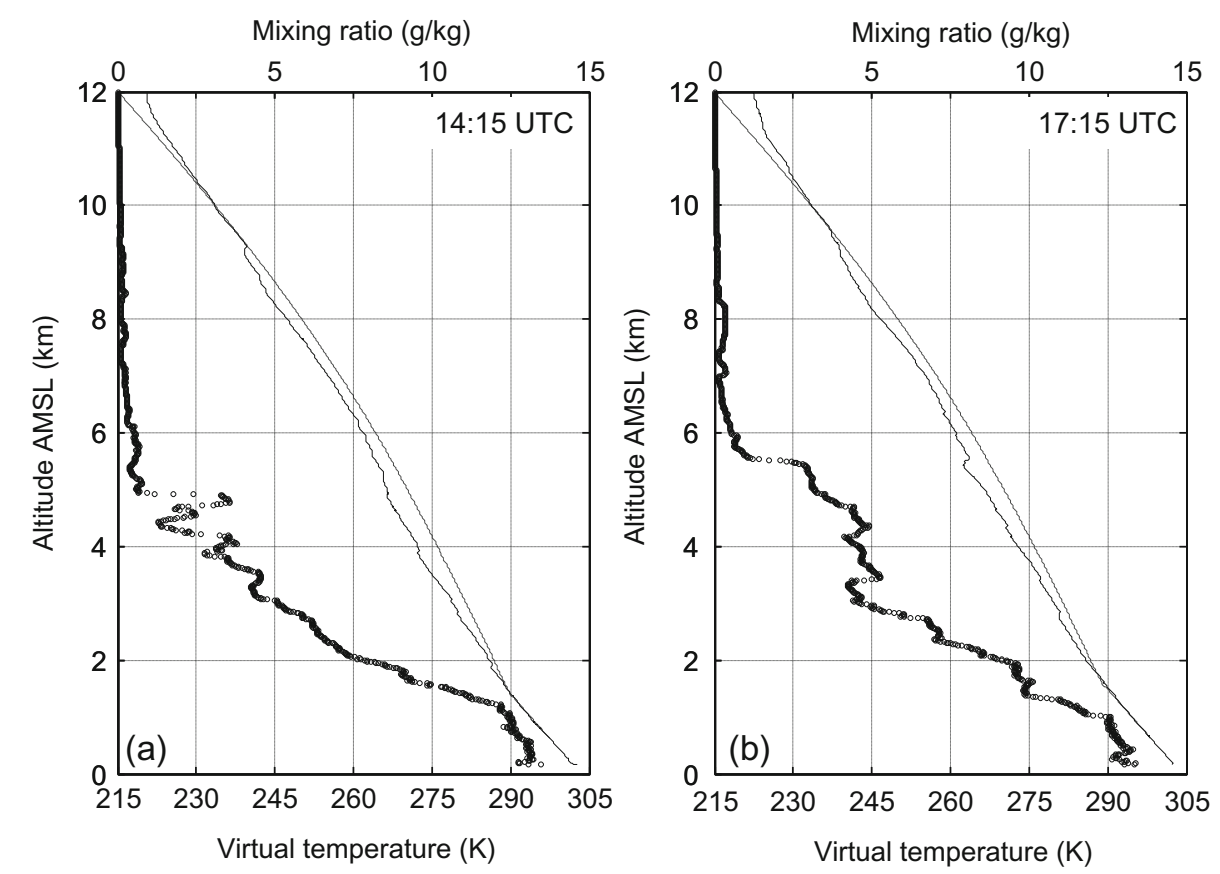

Figure 3: Water vapour mixing ratio (small black circles) and virtual temperature (thin solid line) from the soundings launched from supersite $\mathrm{V}$ at 14:15 UTC (a) and 17:15 UTC (b), July 18, 2007. The dashed line indicates the virtual temperature of an ascending parcel. The CAPE and CIN values given in the text are calculated from this difference between environment and parcel virtual temperature.

$45 \mathrm{dBZ}$ (not shown). Then the cell moves and stretches north-eastward and leaves the Bruche Valley mouth for the centre of the Rhine Valley (Fig. 5d) where the cell develops again and reaches its maximum reflectivity and size at 18:11 UTC (Fig. 5e). Considering the general lightning activity detected by the LIghtning detection NETwork, LINET (BETZ et al., 2009), the maximum total lightning rate is reached between 18:00 and 18:05 UTC (31 return strokes in 5 minutes) when the reflectivity also reaches its maximum. This correlation between rainfall and lightning activity (see inset Fig. 5d, e) has been observed in many studies (TAPIA et al., 1998; SOULA and CHAUZY, 2001) and may be considered as a marker of the mainly convective nature of these cells (as mentioned e.g. in TAPIA et al., 1998; RIVAS SORIANO and DE PABLO, 2003). Moreover, at the same time, the POLDIRAD RHI scan shows that the vertical extension of the convective cloud is up to about $8 \mathrm{~km}$ height and this observation is also in good agreement with the LINET network data which show intra-cloud lightning at an altitude up to $8 \mathrm{~km}$ between 17:42 and 17:58 UTC. Likewise the Meteosat Second Generation (MSG) $10.8 \mu \mathrm{m}$ channel maximum brightness temperature (not shown) is about $240 \mathrm{~K}$ at 18:00 UTC which also corresponds to an altitude of about $8.5 \mathrm{~km}$ (with a surface temperature of $295 \mathrm{~K}$ and assuming a standard vertical temperature gradient). Thus, the multi-instrumental study of this cell shows its deep convective nature. Finally, the cell decay begins after 18:45 UTC when it reaches the north slopes of the Black Forest (Fig. 5f).

At 18:11 UTC, another cell initiates on the lee side of the Vosges, in the Giessen valley area (see location
Fig. 1b, hill no. 4), about $30 \mathrm{~km}$ to the south of the first CI location (Fig. 5e). This cell develops and its reflectivity maximum is about $45-50 \mathrm{dBZ}$ at $18: 45$ UTC (Fig. $5 \mathrm{f}$ ) and greater than $50 \mathrm{dBZ}$ at 18:55-19:05 UTC (not shown). Then, the cell decays and dissipates over the Rhine Valley. The POLDIRAD RHI scan shows a vertical extension up to about $6 \mathrm{~km}$ height at 19:01 UTC but no associated lightning activity is detected. Moreover, the MSG $10.8 \mu \mathrm{m}$ channel (not shown) does not show brightness temperature lower than $260-270 \mathrm{~K}$ at 19:00 UTC which indicates a cloud top altitude of about $5 \mathrm{~km}$ and thus confirms that convection remains shallow. Note that the MSG infrared imager resolution is about $3 \mathrm{~km}$ which should be sufficient in view of the maximum PPI-reflectivity area of the cell which is greater than $5 \mathrm{~km} \times 5 \mathrm{~km}$. However, the difference in resolution between the radar and the satellite is probably responsible for the lower cloud top altitude obtained from MSG data compared to POLDIRAD.

The high resolution $\mathrm{X}$ band radar from LaMP was suitably located to allow for a more detailed analysis of these two convective events. For the first convective event (Fig. 6), there is unfortunately a partial screening in the north-west quadrant (TRIDON, 2011), but we can see that the cell initiates at 16:40 UTC over the northern slopes of the Bruche Valley (Fig. 6a and white star Fig. 1b for the CI location). Then, the cell develops over these slopes, and stretches north-eastward, in a direction which is nearly parallel to the Bruche Valley (Fig. 6b). After 17:00 UTC (Fig. 6c, d), an intensification of the cell is visible around two hills near the Bruche Valley mouth. The reflectivity at the centre of the cell reaches 

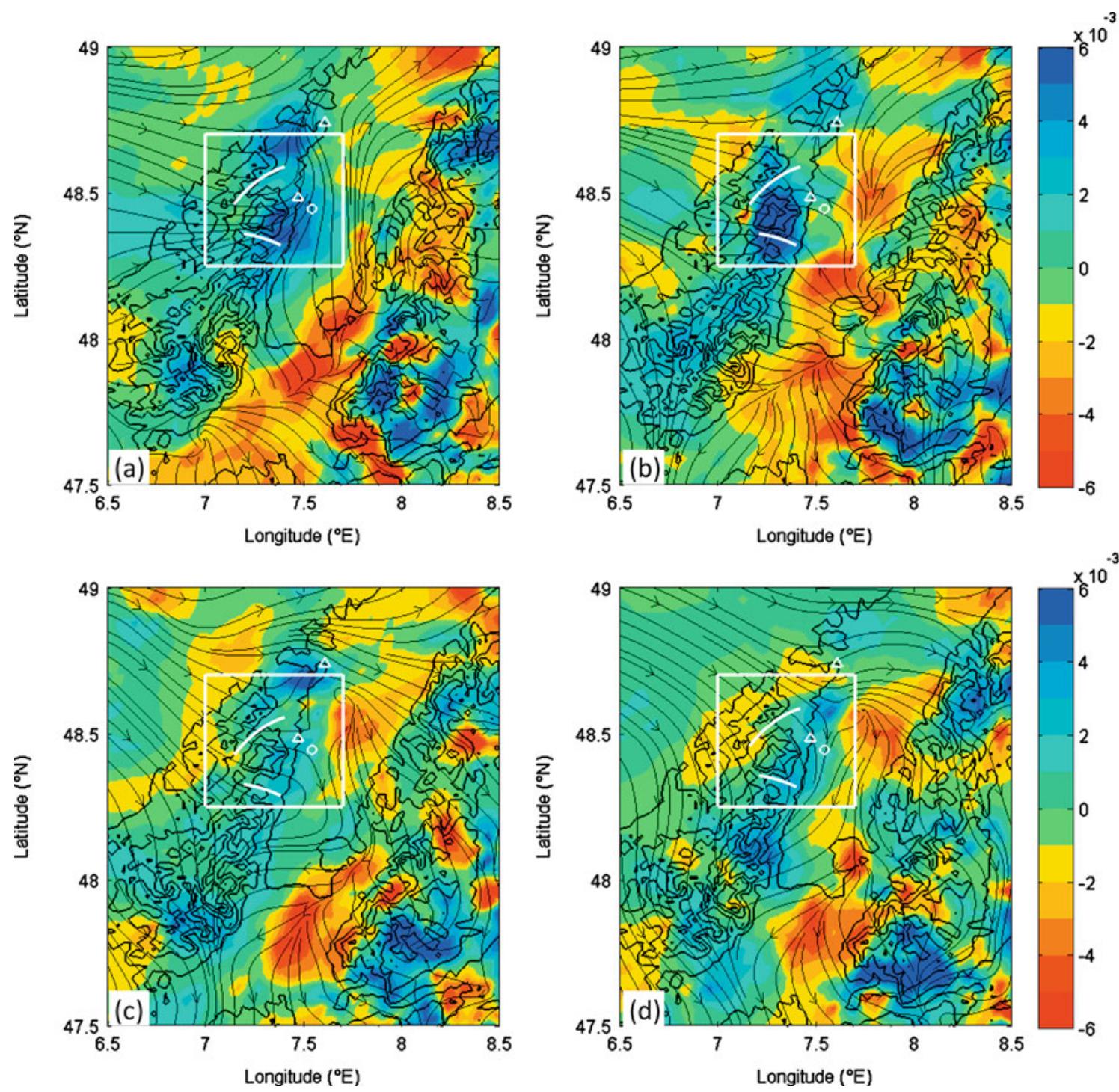

Figure 4: Wind direction (streamlines are thin black lines and arrows) and moisture flux convergence (MFC, colour shading, $\mathrm{g} \mathrm{kg}^{-1} \mathrm{~s}^{-1}$ ) at 10 meters above ground level from Vienna Enhanced Resolution Analysis (VERA) between 14:00 and 17:00 UTC. VERA resolution is $4 \mathrm{~km}$ for both wind and MFC. Thick black solid lines indicate orography. The white rectangle indicates the domain shown in Fig. 1b. The white lines indicate the Giessen Valley (to the South) and the Bruche Valley (to the North). Between these two valleys, the white triangle marks the LaMP X band radar location, and the white circle is for the supersite V. The second white triangle in the north-east of the Bruche Valley indicates POLDIRAD location.

$60 \mathrm{dBZ}$. Then the reflectivity decreases and the cell is advected north-eastward (Fig. 6e). A second enhancement of the cell intensity is observed ten minutes later (Fig. 6f) with a quite large area of high reflectivity $(>50 \mathrm{dBZ}$ ), stretching along the north-east direction, from the hill in the south of the Bruche Valley mouth (see Fig. 1b, no. 3).

In fact, the detailed time series of high temporal resolution radar images (not shown) indicates that these two enhancement periods could also be seen as two individual cells located very close to each other before they merge together (however sometimes with two distinct parts, as in Fig. 5d). It has to be noted that this is not a multicellular storm, as they are usually larger and characterised by new cells formations in front of the oldest cell, which is the opposite here. However, we can expect some interaction between the two cells. Hence, the remaining question is: are these cells two distinct ones or just two enhancement phases of one single convective system? As radar observations show two distinct cells during only a very short period of time and other data are not available with sufficient temporal and spatial resolution, we will consider hereafter that this convective system is composed of one cell with two enhancement phases. After 17:45 UTC the cell remains intense (as seen with POLDIRAD in Fig. 5) but is advected away from the Bruche Valley area and beyond the X band radar range. Thus, the first development phases of the cell seem to be reinforced by interactions with local orography, before the cell grows again over the Rhine Valley. 

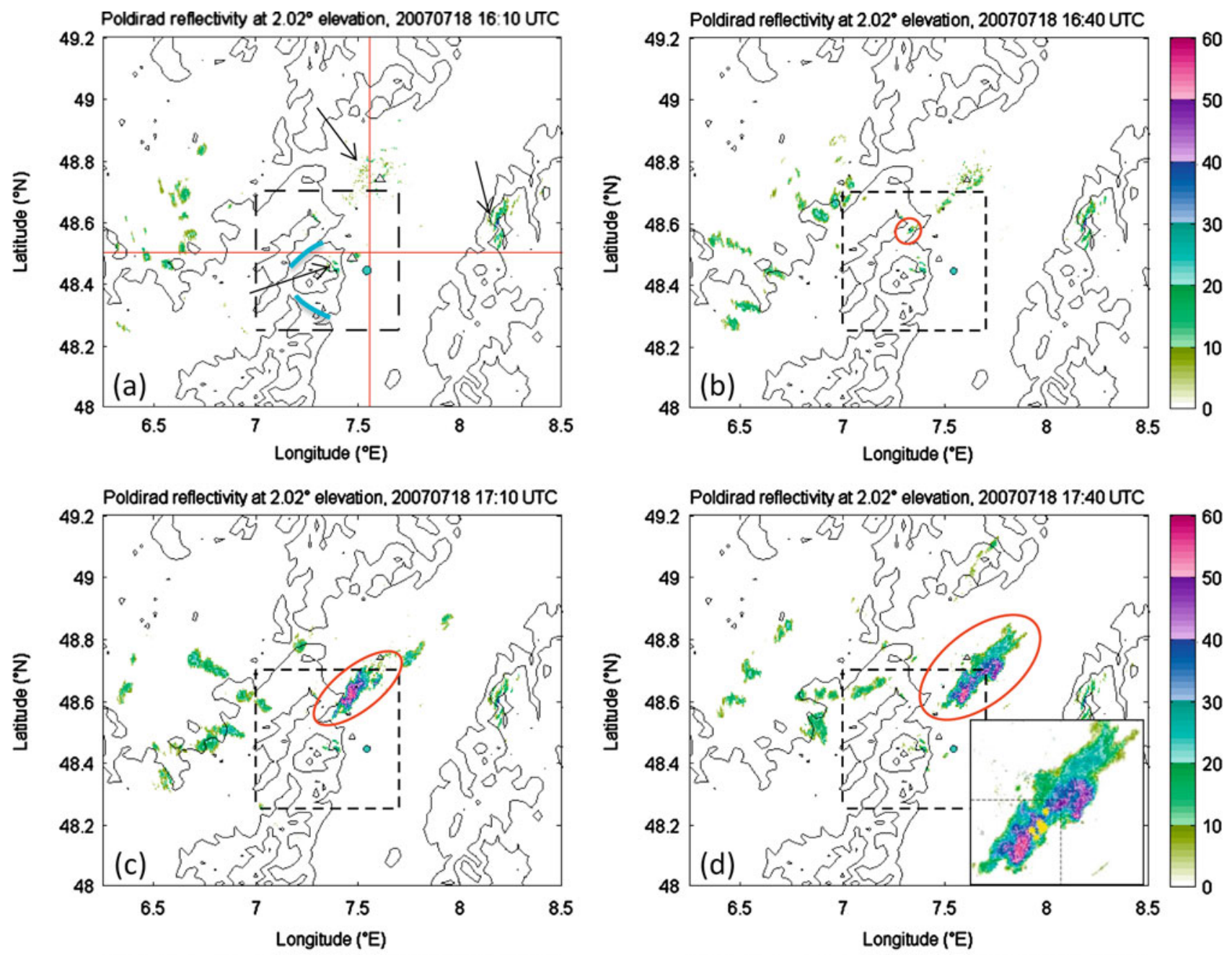

Poldirad reflectivity at $2.04^{\circ}$ elevation, $2007071818: 11$ UTC
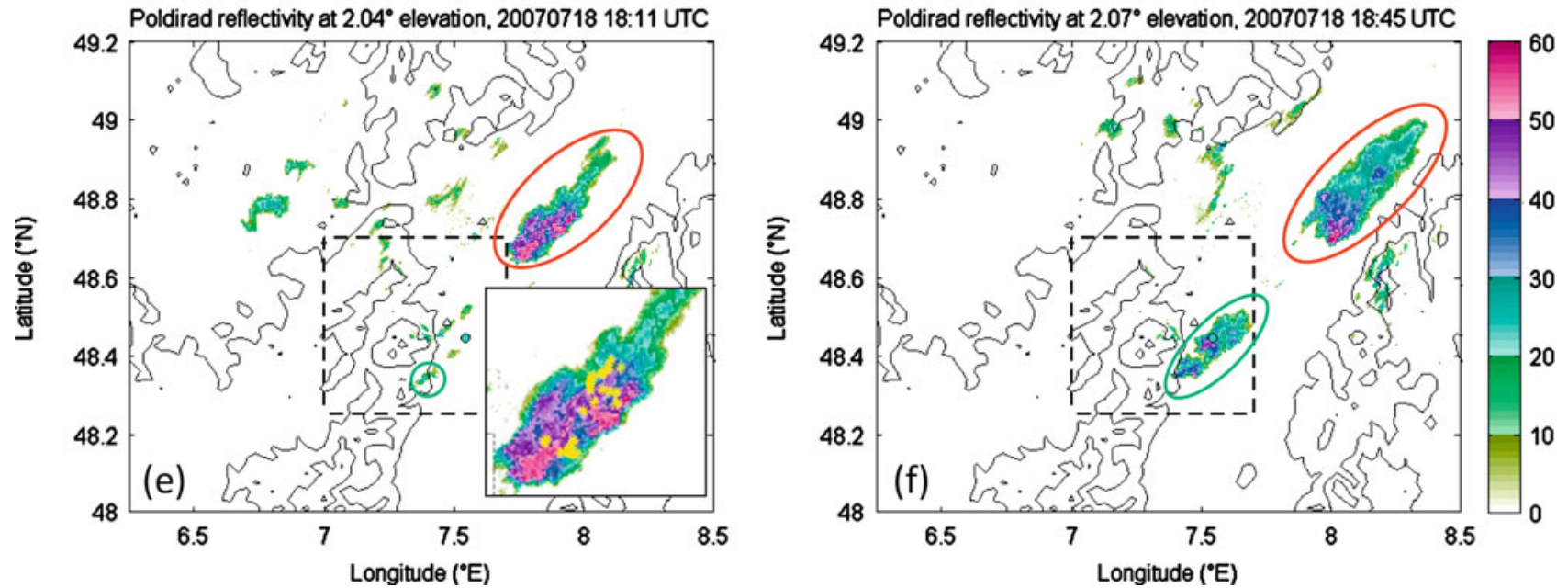

Figure 5: POLDIRAD PPI scans at $2^{\circ}$ elevation, at 16:10 UTC (a), 16:40 UTC (b), 17:10 UTC (c), 17:40 UTC (d), 18:11 UTC (e) and 18:45 UTC (f), on July $18^{\text {th }}$, 2007. Colour scale indicates the reflectivity in dBZ. The supersite V is marked by a blue circle, the X band radar location is the black triangle nearby and the POLDIRAD radar location in the second black triangle, to the north. The dashed black rectangle indicates the area shown in Fig. 1b. The two blues lines indicate the Bruche valley (north) and the Giessen valley (south). The red lines (a) are the directions of the two vertical cross sections shown in Fig. 12. The remaining ground clutters are marked by black arrows (a). Red ellipses (b-f) show the first cell mentioned in the text. The second one is marked by a green ellipse (e,f). The yellow stars in the zooms (inset $d, e$ ) indicate the lightnings detected between 17:42 and 17:45 UTC (d) and between 18:09 and 18:13 UTC (e). 
2007-07-18 at 16:40:30 UTC

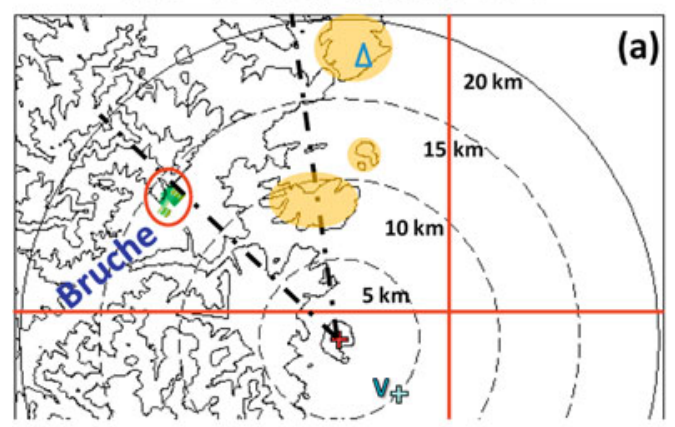

2007-07-18 at 17:02:29 UTC

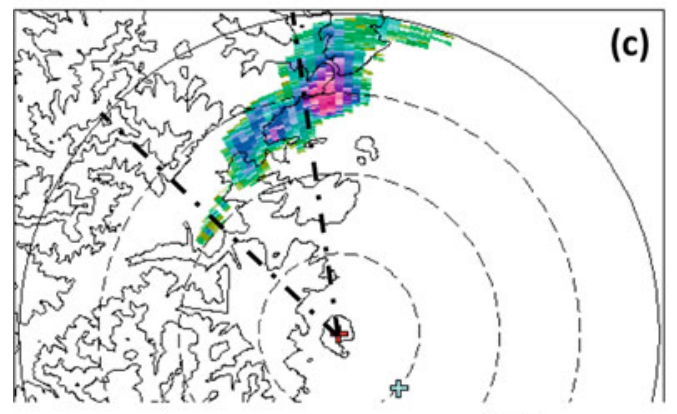

2007-07-18 at 17:21:30 UTC

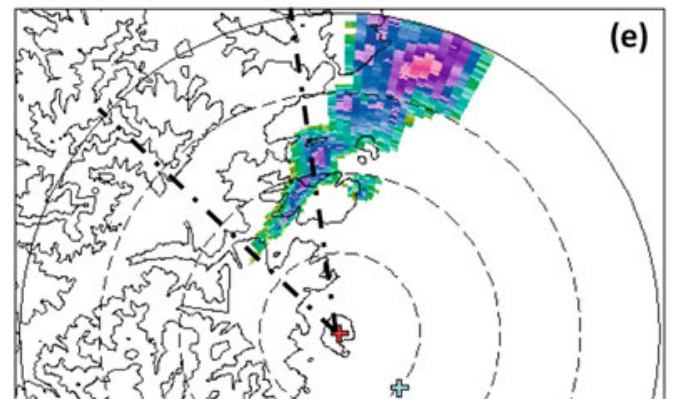

2007-07-18 at 16:51:30 UTC

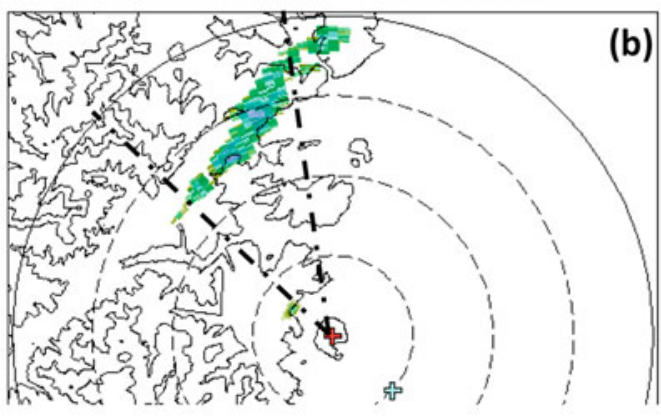

2007-07-18 at 17:11:29 UTC

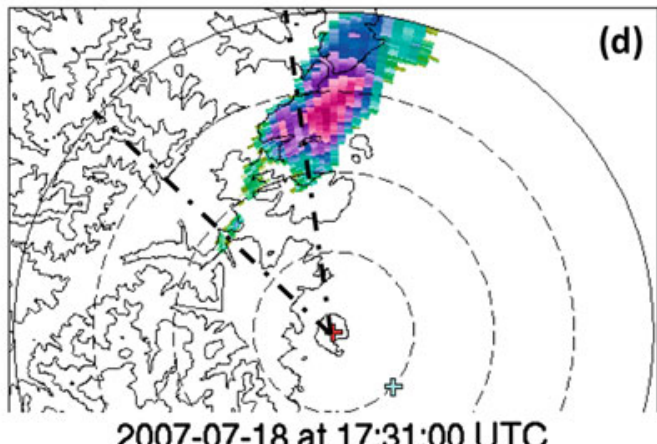

2007-07-18 at 17:31:00 UTC

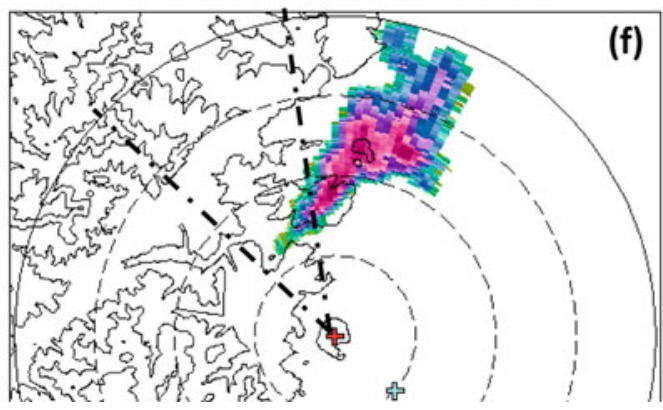

(f)
10

60

50

40

30

20

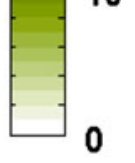

Figure 6: LaMP X band radar reflectivity map (colour scale in $\mathrm{dBZ}$ ) at $5^{\circ}$ elevation (PPI), approximately every 10 minutes between $16: 40$ UTC (a) and 17:31 UTC (f). The topography is represented by solid black contour lines, the first line corresponds to $250 \mathrm{~m}$ above mean sea level, and then the lines are plotted every $200 \mathrm{~m}$. The red cross shows the radar location and the clear blue cross south-east of the radar is the supersite $\mathrm{V}$ location. The area within the two dashed bold lines corresponds to an area of partial blocking where reflectivity is underestimated. The river name is written in blue (a), the red circle indicates the first signal of CI activity detected by the radar (see also the white star in Fig. 1b), and the three hills highlighted with orange-transparent marking are those shown in Fig. 1b (number 1 to 3, from north to south). The two red lines (a) indicate the locations of the cross-sections shown in Fig. 12. The blue triangle (a) indicates the location of the in-situ measurement station mentioned in the text.

PLANCHE et al. (2013) also studied this convective cell using the high resolution cloud resolving model of CLARK et al. (1996). A comparative study between the observations and simulations during the first enhancement phase shows that the simulated and observed radar reflectivities are comparable (PLANCHE et al., 2013). In order to investigate the role of the orography on the first enhancement of this convective system, a sensitivity study was performed by modifying the topography close to its initiation point, i.e. removing hills at the exit of the Bruche valley (labelled 2 and 3 in Fig. 1b). This topography modification does not affect the first enhancement phase of this convective system (Fig. 7a, b). This means that those hills do not play any noticeable role at this time.

During the second enhancement of the convective system (Fig. 7c, d), the impact of the hills present in the mouth of the Bruche valley becomes visible since the intensity of the cell is considerably lower when the topography is modified. Hence, these model simulations confirm that the second enhancement of the cell is triggered by the orography.

In conclusion, according to radar observations, the triggering of the first convective event seems to be affected by the northern slopes of the Bruche valley and also by a secondary valley mouth (at the location 


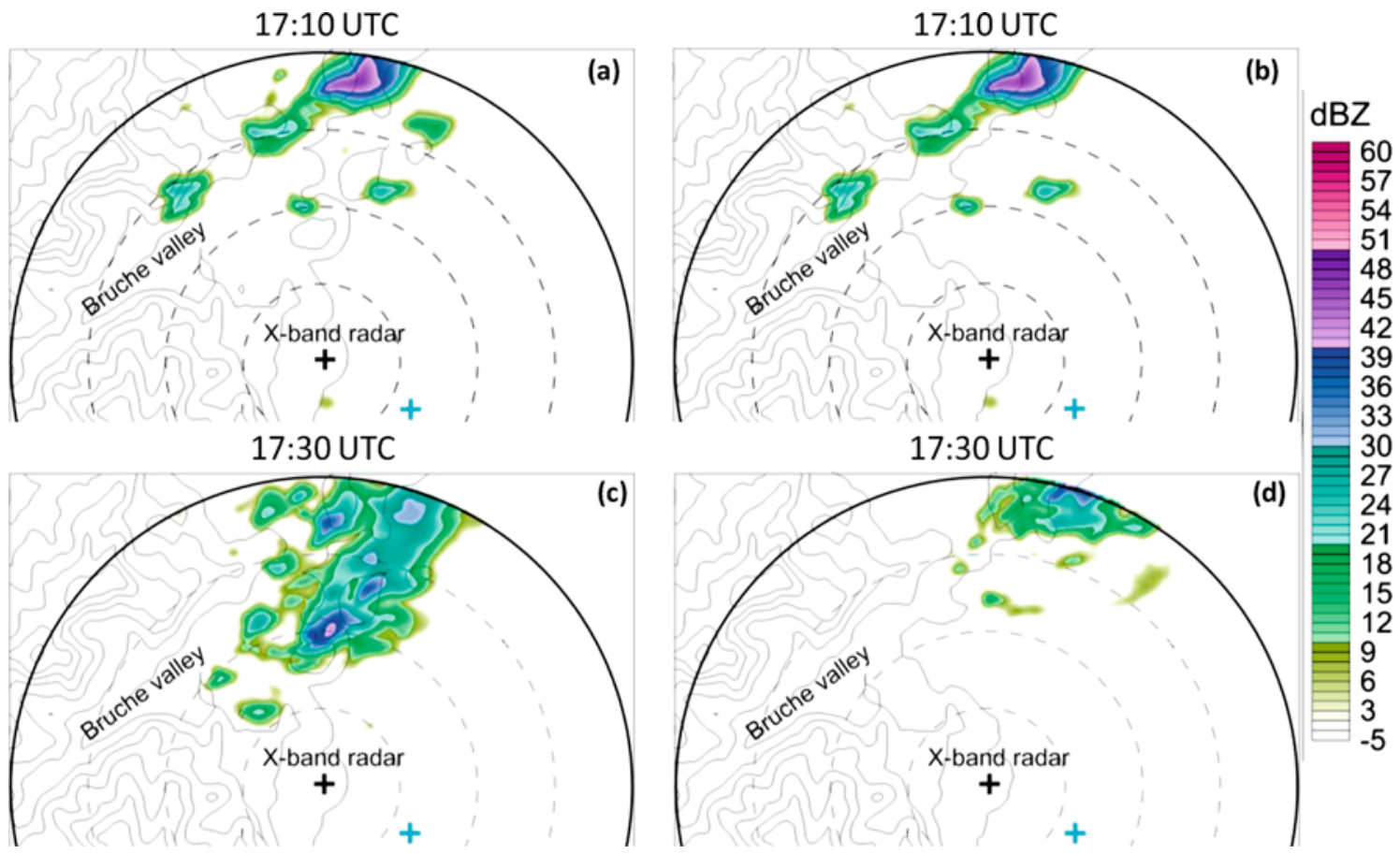

Figure 7: Radar reflectivity (colour scale, dBZ) simulated using the high resolution cloud resolving model of CLARK et al. (1996) at 17:10 UTC $(a, b)$ and 17:30 UTC (c,d). The lines represent the topography used by the model. They are every $100 \mathrm{~m}$ (beginning at $200 \mathrm{~m}$ height). In $(\mathrm{a}, \mathrm{c})$ the topography is the "real" topography, while in $(\mathrm{b}, \mathrm{d})$ the hills in the mouth of the Bruche valley have been removed. Details about the simulation set-up are given in PLANCHE et al. (2013). The blue cross indicates supersite V.

of CI at 16:40 UTC, see Fig. 6a and also the white star in Fig. 1b). Then, two distinct enhancement phases are visible in the formation of the convective system. The first one seems to be affected by the northern slopes of the Bruche valley (no. 1 in Fig. 1b) whereas the second one is triggered by the hills situated in the mouth of the Bruche valley (no. 2-3 in Fig. 1b).

The first echoes of the second convective event (Fig. 8) are detected by the X band radar at 18:07 UTC. Their location coincides with a hill in the north of the Giessen Valley mouth (no. 4 in Fig. 1b). We cannot be completely sure that the precipitating cell has not been advected into the radar range as they appear near the maximum range of the radar and no other high resolution radar observation is available. However at 18:10 UTC (Fig. 8a), the cell is very small with low reflectivity $(<20 \mathrm{dBZ})$. Thus, even if the cell existed before 18:07 UTC and has been advected, it was not yet a convective cell. Furthermore POLDIRAD observations (Fig. 5e) seem to confirm this hypothesis as no active cell is detected in that area or upwind before its detection by the LaMP X band radar. Once detected the cell size and reflectivity increase quickly and by 18:20 UTC the cell stretches north-eastward over approximately $10 \mathrm{~km}$ and reaches a maximum reflectivity of about $50 \mathrm{dBZ}$ (Fig. 8b). Then the major part of the cell detaches from the hill side and moves into the Rhine valley, while the reflectivity reaches up to $60 \mathrm{dBZ}$ (Fig. 8c) before decaying and enhancing again (Fig. 8d-f) up to 19:05
UTC when it starts fading away. At the same time the convective cell moves away from the mountains and a new cell seems to initiate again at the same spot in the mouth of the Giessen valley. Likewise, regeneration / new cell formation and mixing with previous cells being advected over the Rhine continue till 19:10 UTC. Hence, cell initiation / regeneration occurs many times at the same location, which points to the essential role of local orography on convection.

In conclusion, during that afternoon, all the convective cells initiate on the east part of the Vosges Mountains and more particularly near the mouths of the valleys. High resolution observations and numerical model sensitivity study both show the crucial role of fine scale orography on convection initiation and enhancement on the lee side of the Vosges Mountains during IOP9a.

\subsubsection{Wind and water vapour dynamics}

VERA shows complex wind and MFC features at ground level, with rapid changes in the Rhine Valley during the afternoon (Fig. 4). At 13:00-14:00 UTC a moderate $\left(5-6 \mathrm{~m} \mathrm{~s}^{-1}\right)$ westerly flow crosses the Vosges Mountains between the Bruche and the Giessen Valley. The wind speed then decreases and at 15:00 UTC, the flow is mainly split by the Vosges mountains. This flow splitting is nevertheless associated with a partial crossing, especially on the northern part of the Vosges. A local MFC and a low wind zone are observed over the crests and 

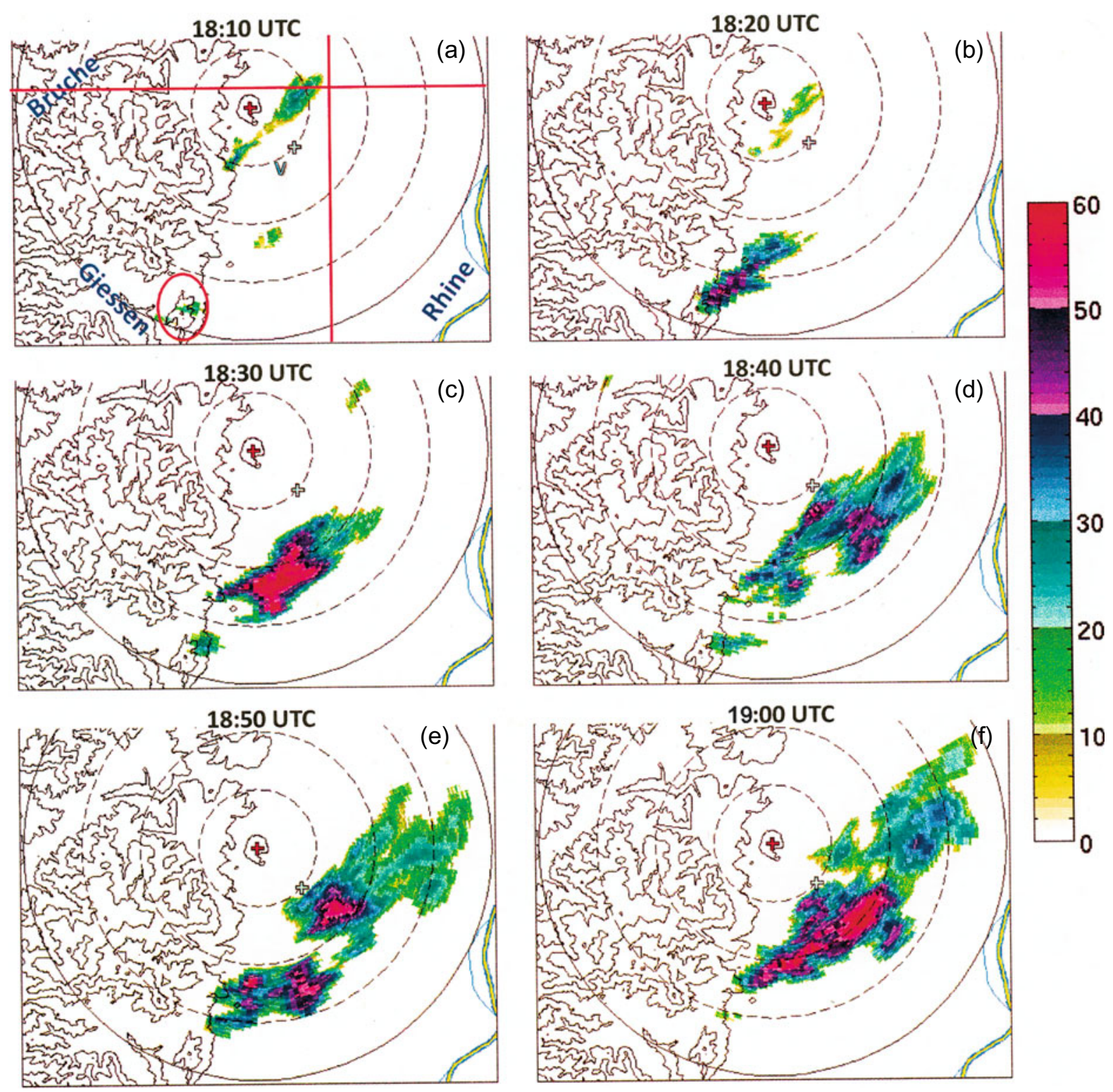

Figure 8: LaMP $X$ band radar reflectivity map, as in Fig. 6 but for the second cell mentioned in the text. PPI scans are given every 10 minutes, from 18:10 (a) to 19:00 UTC (f). The hill no. 4 shown in Fig. 1b is inside the red circle (a), which also corresponds to convective initiation location. The names of the main rivers are written in blue in (a).

in the Bruche valley. At 16:00 UTC the crossing is more marked, and the wind regime in the Rhine valley has changed from a mainly northward flow to a mainly southward flow, and the MFC at ground level decreases over the Vosges crests and in the Bruche Valley. At 17:00 UTC, the situation is quite similar and the convergence zone moves southward. During that period (from 15:00 to 17:00 UTC) we observe the strong influence of upstream wind direction on the valley wind regime and convergence areas. Indeed, the very small clockwise rotation of the wind in the north-west of the domain leads to an inversion of the wind direction and a modification of the convergence zone locations in the Rhine Valley. This is consistent with previous studies (e.g. BANTA,
1990; HAGEN et al., 2011) mentioning the major influence of wind direction on precipitation in mountainous areas.

By 18:00 UTC (not shown), there is no more MFC zone in the Bruche valley area and even a moisture divergence zone coupled with a northerly/north-westerly wind enhanced in the mouth of the Bruche valley. Further south, the wind is nearly parallel to the Vosges crests.

Complementary observations are given by the UHF wind profiler at supersite V (Fig. 9) which indicates a moderate horizontal wind in the lower part of the troposphere $\left(<10 \mathrm{~m} \mathrm{~s}^{-1}\right.$ below $2 \mathrm{~km}$ AMSL, Fig. 9a). The wind profiler shows that in the low atmosphere (up to $1 \mathrm{~km}$ AMSL) the wind direction changes between 


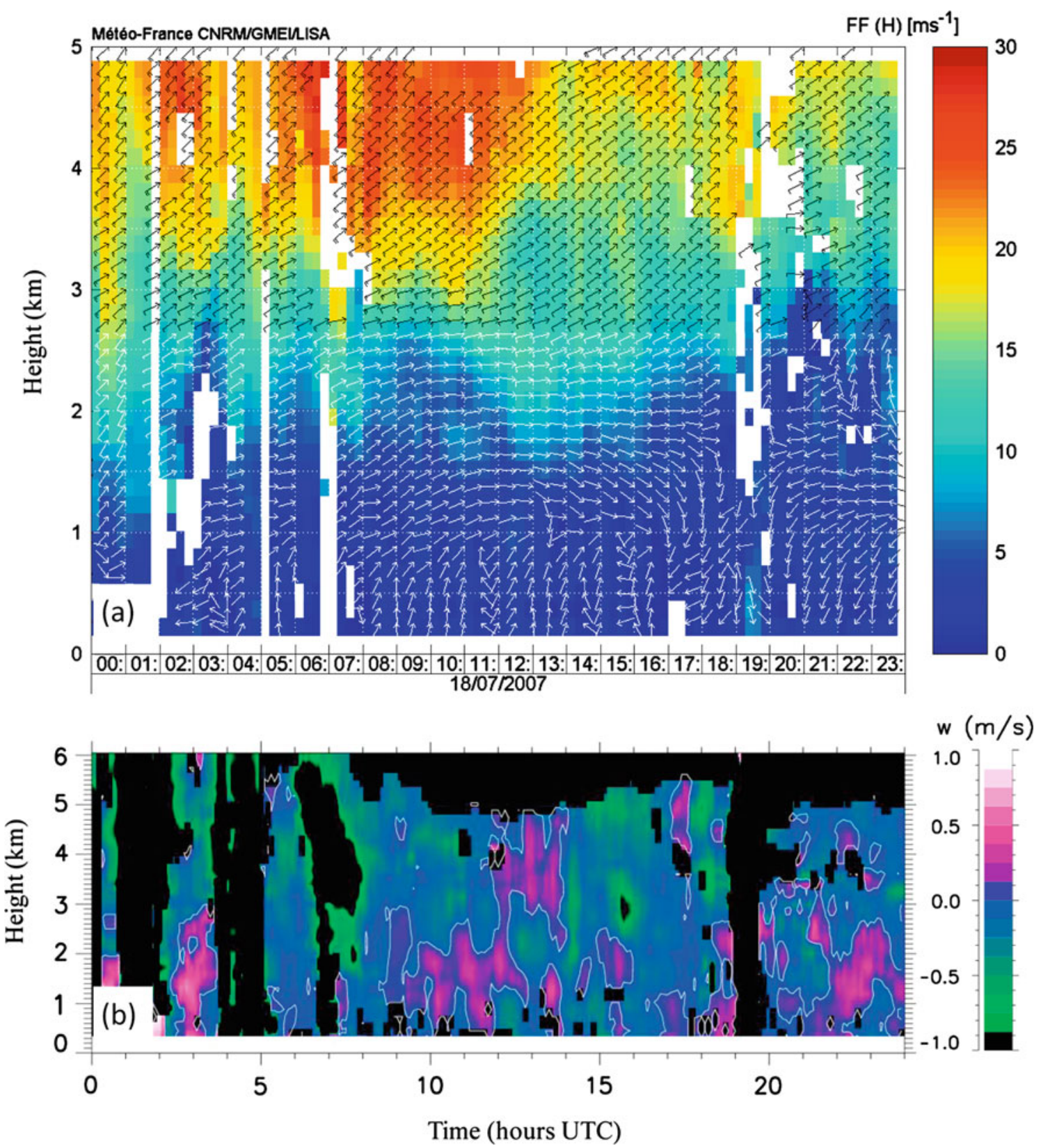

Figure 9: Horizontal wind speed and direction (a, adapted from what shown in VAN BAELEN et al., 2011) and vertical wind speed (b) from the UHF wind profiler at supersite V. The white lines (b) surround positive vertical winds.

16:00 and 17:00 UTC, from southerly to north-easterly. This confirms the changes in wind direction observed in the VERA data. This change appears thus to affect not only the surface layer but the low atmosphere up to about $1 \mathrm{~km}$ of height. Wind profilers are also sensitive to precipitation via Rayleigh scattering (RALPH, 1995). Hence, the vertical Doppler velocity measurements during precipitation are actually a combination of the hydrometeors fall speed and vertical wind. Overall, apart from the strong Doppler velocities toward the ground associated with precipitation (Fig. 9b, black columns in the morning and between about 19:00 and 20:00 UTC) there is no specific features which could indicate the presence of a mountain wave. The observed vertical winds are very moderate.

The VERA mixing ratio (Fig. 10) reveals two moist areas in the Rhine Valley, respectively in the north-east and in the south-east of the Vosges Mountains. The first one remains humid between 14:00 and 17:00 UTC (however with a slow and light drying of less than $1.5 \mathrm{~g} \mathrm{~kg}^{-1}$ in 3 hours) while the second one in the south-east part of the Vosges Mountains dries stronger (about $3 \mathrm{~g} \mathrm{~kg}^{-1}$ in 3 hours). The later drying contrasts with the MFC values which are mainly positive during this period (Fig. 4). This could be due to the turbulent mixing of moisture within the boundary layer especially if the boundary layer 


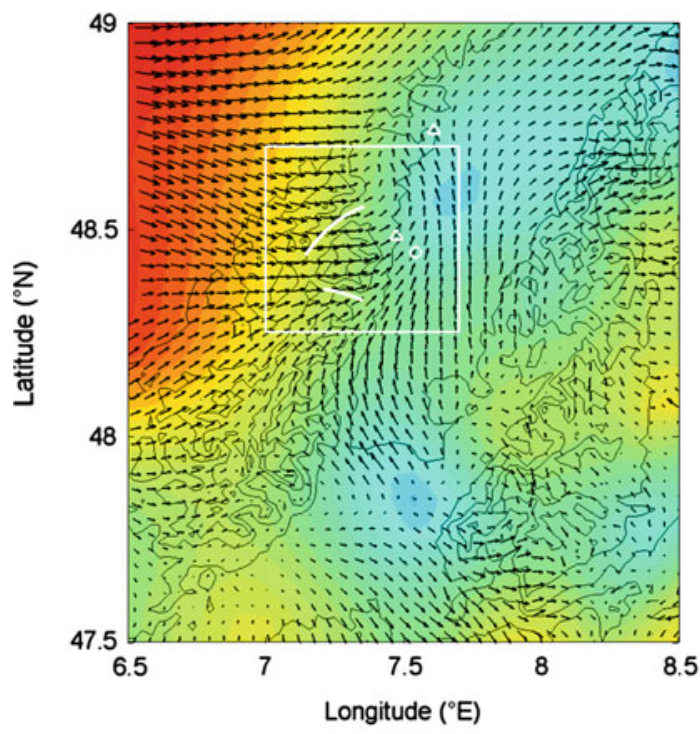

(a)

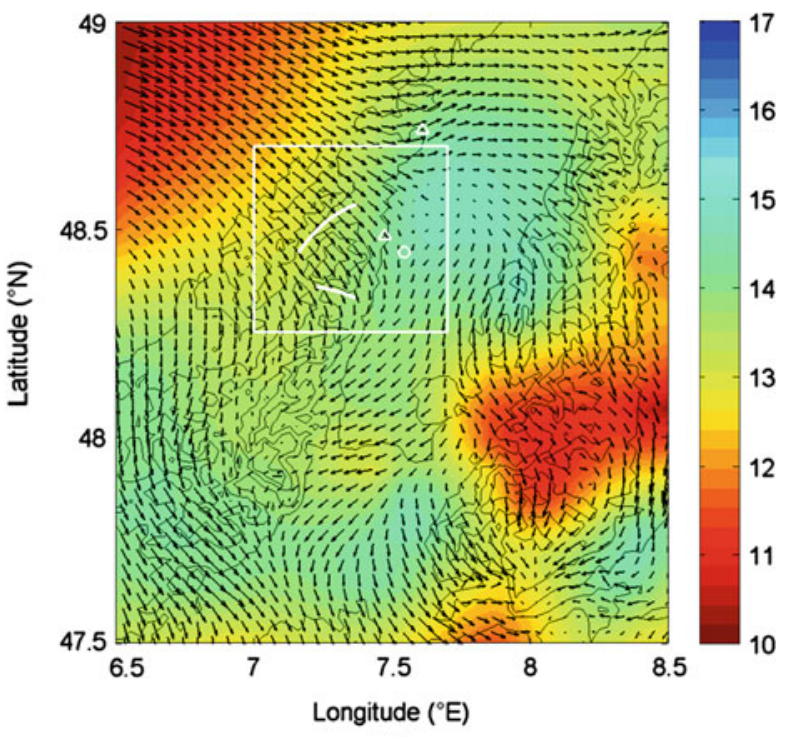

(b)

Figure 10: VERA water vapour mixing ratio (colour shading, $\mathrm{g} \mathrm{kg}^{-1}$ ) at $2 \mathrm{~m}$ above ground level (AGL) and wind direction (black arrows) at $10 \mathrm{~m} \mathrm{AGL}$, at 14:00 UTC (a) and 17:00 UTC (b). VERA resolution is $4 \mathrm{~km}$, for both wind and mixing ratio. The white rectangle indicates the domain shown in Fig. 1b. The two white lines indicate the Bruche (north) and Giessen (south) valleys. The white circle indicates the supersite V, and the white triangles are for POLDIRAD (north) and the LaMP X band radar (near supersite V). Topography is shown by the thin black contours.
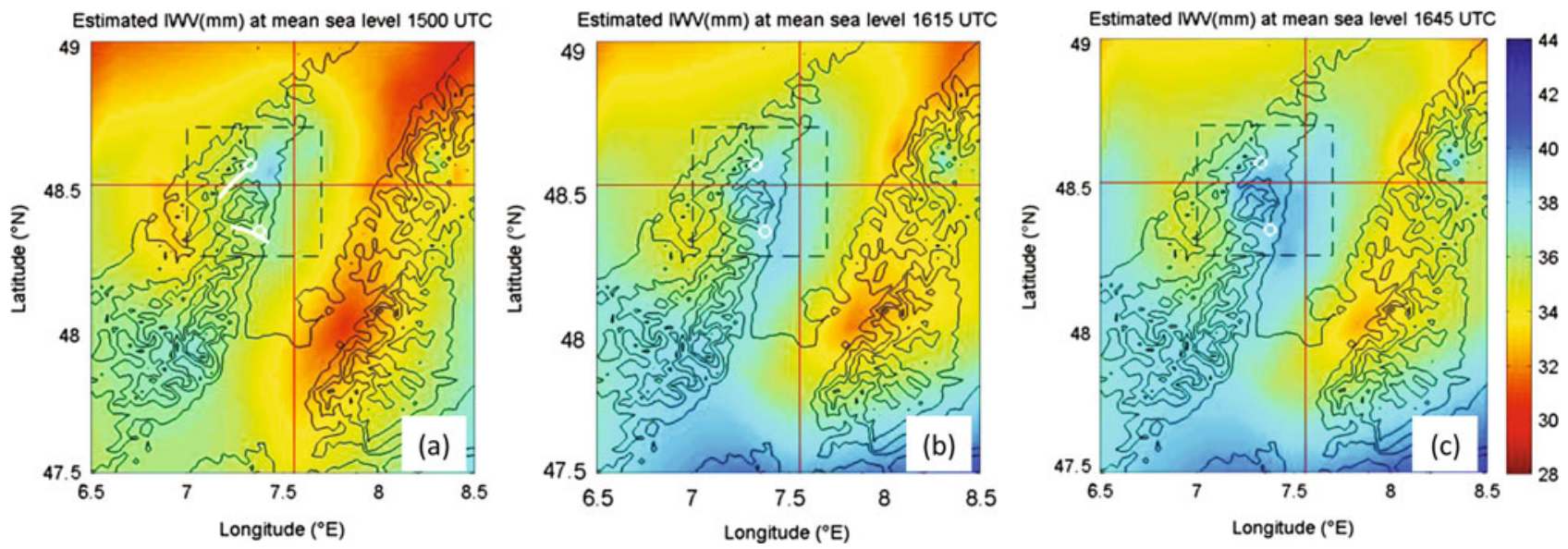

Figure 11: Integrated Water Vapour $\left(\mathrm{kg} \mathrm{m}^{-2}\right.$ ) estimated at the $1000 \mathrm{hPa}$ pressure level from GPS ground station data, at 15:00 (a), 16:15 (b) and 16:45 UTC (c). The two small white lines (a) indicate the Bruche valley (north) and the Giessen valley (south). The black dashed rectangle refers to the area shown in Fig. 1b, and the two red lines correspond to the vertical cross-sections shown in Fig. 12. The two circles indicates the convection initiation locations of the first cell (in the Bruche Valley, Fig. 6a) and of the second cell (over a hill near the Giessen valley mouth, Fig. 8a).

depth is extending vertically under the influence of surface heating, which will also tend to increase surface drying. The radiosoundings at supersite $\mathrm{V}$ are of little use to help us to understand better the situation as supersite $\mathrm{V}$ lies outside of the concerned area (Fig. 3 shows that in the lowermost atmosphere the mixing ratio remains nearly constant, with values between $12.7 \mathrm{~g} \mathrm{~kg}^{-1}$ and $13.5 \mathrm{~g} \mathrm{~kg}^{-1}$ ). Hence, we can see here the limits of using only surface data, which are known to be most of the time insufficient (MUELLER et al., 1993) but also the limits of a single measurement point as for radiosoundings. Nevertheless, we can notice that mixing ratio on the east (lee) side of the mountain range is (and remains) significantly high compare to the other side, creating favourable conditions for convective initiation. The origin of the moist pouch which develops in the north-east of the Vosges Mountains from 12:00 UTC (not shown) seems to be linked with precipitation which occurs in the early morning, following by moisture flux convergence at ground level from 10:00 UTC.

We cannot go much further on the interpretation of the origins of $\mathrm{CI}$ and convective enhancement using only 
surface data because they do not give information about the water vapour in higher levels which is important for the convection. That is why the GPS measurements can be so valuable.

According to GPS IWV measurements, there is a moist band along the north-east part of the Vosges Mountains from about 15:00 UTC (Fig. 11). Within this band we observe a significantly moister area near the Bruche valley mouth. From 16:15 to $16: 45$ UTC, the enhancement of this moist area is visible, growing from the zone between the Bruche valley and the Giessen valley toward the Bruche valley and the mountain ridges. This moistening confirms that the light decrease of the mixing ratio at low level is counterbalanced by mixing in the boundary layer. This moistening has to be linked with the switch of the wind direction in the Rhine valley which leads to the observed lee side wind convergence and MFC between 16:00 and 17:00 UTC (Fig. 4). We further notice that this time frame corresponds to the first CI detected by the LaMP X band radar (16:40 UTC, Fig. 6a).

Furthermore, GPS tomography provides one further step in the water vapour field description to understand its interactions with the convective systems and orography (VAN BAELEN et al., 2011). From the 3D GPS tomography results, we will use here two vertical crosssections, one at constant latitude of $48.5^{\circ} \mathrm{N}$ (latitude of the voxel centres) and the other at constant longitude of $7.56^{\circ} \mathrm{E}$ (see red lines Fig. 11) which crosses through the principal area of interest.

Using the first vertical cross-section, Fig. 12 shows the development (12:00-15:00 UTC) and maintenance (15:00-18:00 UTC) of a very moist area in the low troposphere over the lee of the Vosges Mountains and the western part of the Rhine Valley, which later spreads quickly to the east at 17:50-18:00 UTC, mainly below $500 \mathrm{~m}$ AMSL. Thus, between 15:00 and 17:30 UTC, there is thus a rather intense east-west water vapour gradient below $2 \mathrm{~km}$ AMSL (see Fig. 12b, c). The beginning of the precipitation associated with the first convective event (at 16:40 UTC according to X band radar, Fig. 6a) occurs during this period. The water vapour depletion observed over the eastern Rhine Valley is certainly linked to low troposphere dynamics. Indeed, as shown in Fig. 4, the moisture flux divergence seen over the east part of the Rhine Valley at ground level contrasts with the local MFC observed over the crest and the east part of the Vosges Mountains.

Likewise the tomography longitudinal cross section shows that the humidity is localised in the vicinity of the precipitation area at the exit of the Bruche Valley, with the moistest part between about $48.4^{\circ} \mathrm{N}$ and $48.6^{\circ} \mathrm{N}$ during the afternoon. Then, this area moves slightly to the south after 17:10 UTC, whereas the north part dries (about $49^{\circ} \mathrm{N}$ ) from 17:45 UTC (not shown, but see the evolution between 15:00 and 18:00 UTC, Fig. 12d-e). This is associated with the second cell initiation which occurs at about 18:10 UTC (Fig. 8a).
Thus, the tomography confirms and clarifies what the IWV maps suggested. Furthermore, the synergy between tomographic results and high resolution $\mathrm{X}$ band radar reflectivity maps indicates that the first development phases of the first cell seem to be reinforced by the interactions with the local orography in an area where a high amount of water vapour is available and associated with a local MFC and wind convergence at ground level as shown with VERA.

When the cell grows again as it moves over the Rhine Valley, it is associated with a modification of the water vapour field. Indeed GPS tomography indicates that from 17:45 UTC the moist zone spreads eastward in the Rhine valley. Moreover, higher resolution tomography performed in this case with $15 \mathrm{~km}$ horizontal resolution instead of $30 \mathrm{~km}$ (not shown) shows a very localised moist area which appears near the convection enhancement location at 18:00 UTC. This area remains very moist till 19:00 UTC while, according to POLDIRAD, the system begins to decay after 18:45 UTC (Fig. 5f). However, this moistening of the low atmosphere is not linked to any significant moisture flux convergence at the low level. It is very localised and increases quickly. This leads us to believe that this moisture spot is due to precipitation evaporation. Thus, this second phase enhancement, without any direct orographic effect, could be linked to the synoptic low level convergence line observed in the analysis at 18:00 UTC but not at 12:00 UTC (Fig. 2c, d). Again, the data available will not allow us to go further in the interpretation of the convective enhancement over the Rhine valley for which finer scale measurements or model studies are needed.

The GPS tomography vertical resolution is $150 \mathrm{~m}$ close to the ground but this is only relevant if enough SWDs are available in the corresponding near surface voxels. Thus, very local measurements at surface based meteorological stations near the cell enhancement location could give complementary information about the surface layer thermodynamics. Unfortunately, only a few in situ measurements have been made in the area of interest. So we focus on the measurements made at the ground station on the hill to the north of the LaMP $\mathrm{X}$ band radar position (measurement station at $48.64^{\circ} \mathrm{N}$, $7.488^{\circ} \mathrm{E}, 375 \mathrm{~m}$ height, marked by a blue triangle in Fig. $6 a$, the hill is no. 1 in Fig. 1a). The moisture data show a very small mixing ratio enhancement between 15:00 and 16:00 UTC $\left(+0.5 \mathrm{~g} \mathrm{~kg}^{-1}\right.$ in one hour) and then a quick decrease (about $-2 \mathrm{~g} \mathrm{~kg}^{-1}$ between 16:00 and 17:00 UTC). No significant moisture accumulation is seen at ground level. The temperature between 15:00 and 17:00 UTC remains quite constant (about $25^{\circ} \mathrm{C}$ ) and decreases of $3{ }^{\circ} \mathrm{C}$ between 17:00 and 18:00 UTC (associated with an increase of water vapour mixing ratio and so mainly due to precipitation evaporation). Thus, contrary to the low troposphere moisture dynamics, the local ground thermodynamic conditions do not seem to play any important role in precipitation enhancement 

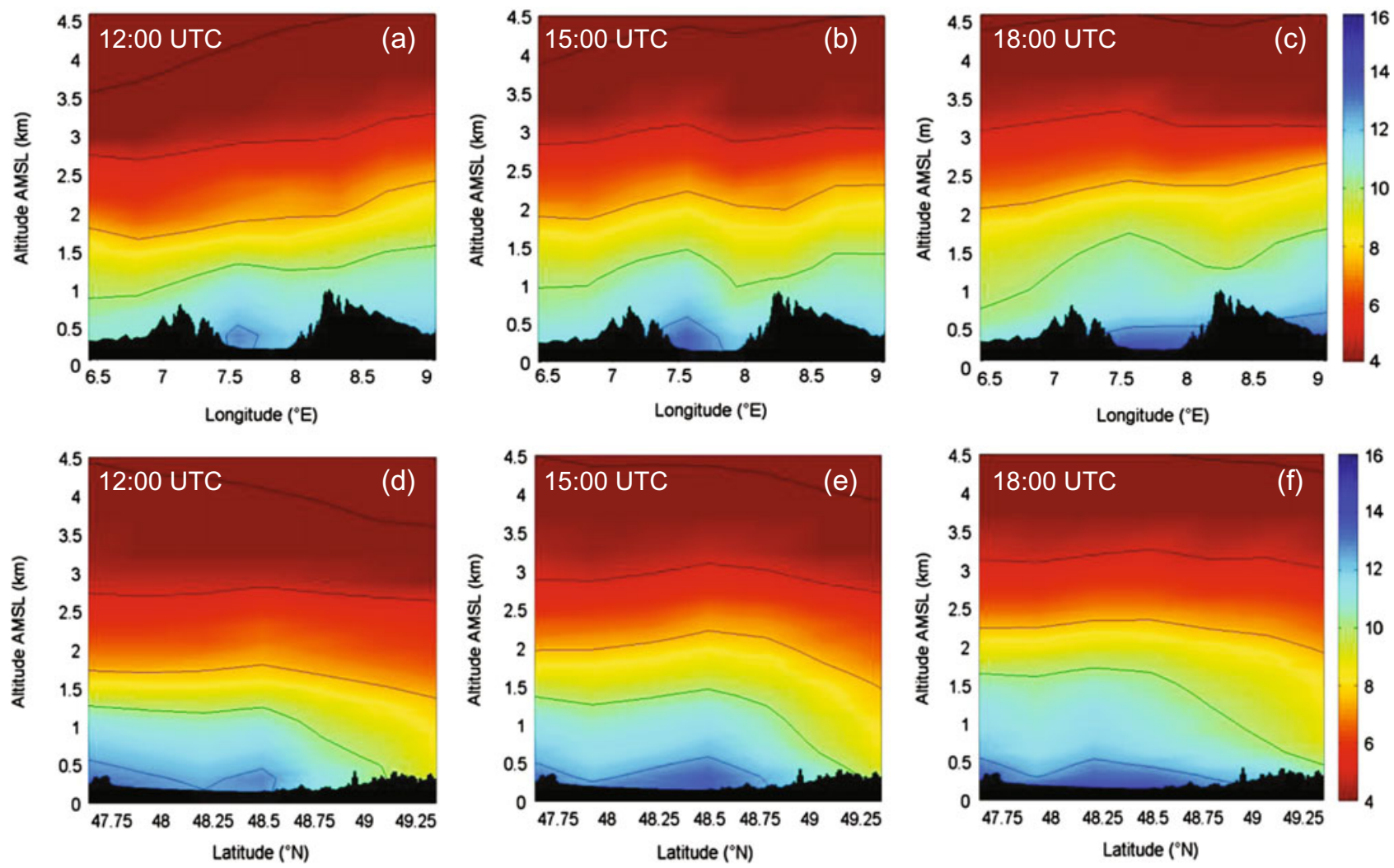

Figure 12: Vertical cross-sections of the water vapour density $\left(\mathrm{g} \mathrm{m}^{-3}\right)$ at the latitude $48.5^{\circ} \mathrm{N}(\mathrm{a}-\mathrm{c})$ and at the longitude $7.56^{\circ} \mathrm{E}$ (d-f) obtained from GPS tomography (location of the cross-sections are marked by red lines on previous figures). Black shading indicates the topography. Black solid lines are iso-density lines (constant water vapour density of $15 \mathrm{~g} \mathrm{~m}^{-3}, 12.5 \mathrm{~g} \mathrm{~m}^{-3}, 10 \mathrm{~g} \mathrm{~m}^{-3}, 7.5 \mathrm{~g} \mathrm{~m}^{-3}$ and $5 \mathrm{~g} \mathrm{~m}^{-3}$ ).

over the hill. This does not mean that surface moisture itself is not important but rather that in the present case the water vapour is not provided to the convective system through an enhancement of the local moisture via surface fluxes, but through moisture advection around the convection enhancement location.

\section{Summary and conclusions}

In this case study, we have shown how the synergy of different observations and measurement techniques could benefit the analysis of convective initiation and enhancement in a complex convective environment. Thus, the synthesis of observations from two radars, GPS IWV and tomography, VERA fields, UHF wind profiler, MSG images and LINET data enabled to provide a quite extensive and detailed description of two major precipitation events observed on the $18^{\text {th }}$ of July 2007 on the lee side of the Vosges Mountains.

In particular, we distinguished between a first deep convective cell and a second shallower convective shower, and showed their local interactions with orography at meso- and local scale. The meso-scale orography (the Vosges mountain range) creates favourable conditions on the lee side by generating convergence near the Bruche Valley before the first CI event, while the small scale orography plays an important role by triggering convective initiation and enhancement.

Wind and associated moisture convergence are well known as significant contributor to convective initiation. Indeed, GPS IWV fields and tomography results reveal increased moisture accumulation along most of the Vosges lee side during the afternoon. In particular, GPS tomography indicates a strong water vapour density gradient between the lee slopes of the Vosges Mountains and the Rhine valley, and a pouch of high humidity can be identified in the area of CI before the onset of precipitation. This available moisture allowed for more intense convection and led to thunderstorm development with associated lightning activity. The origin of this moisture seems to be mainly due to low level moisture flux convergence within the boundary layer (BEHRENDT et al., 2011). This convergence is due to a small modification in the mesoscale wind field in the north-west of the COPS domain. Indeed, this change induces an inversion of the wind direction within the Rhine valley and local convergence along the lee side of the Vosges Mountains. Thus the dynamics and the CI are very sensitive to the wind direction upstream of the mountain range. Furthermore, high resolution radar observations show that local orographic features at the mouths of valleys coincide with the triggering and enhancement of the convective activity. 
In contrast, the later enhancement of the cell over the Rhine valley does not result from any new influx of water vapour in the atmosphere, but lead to a localized moistening through precipitation evaporation. This convective enhancement could be due to modification in synoptic conditions, mainly the formation of a large-scale convergence line at 18:00 UTC.

The second event meets less favourable local dynamical conditions and a slightly lower water vapour mixing ratio allowing only moderate convection activity. Although the different cells of the second event seem to be linked to orography for their initiation / regeneration, their enhancement occurs mainly away from the mountains. They do not reach the mature stage, although they produce locally high radar reflectivity.

Thus, convective initiation on the $18^{\text {th }}$ of July 2007 occurs in two different locations and GPS tomography indicates that water vapour plays an important role as precursor of convective initiation. The LaMP X band radar observations and the sensitivity study made with the cloud-scale Clark model show the strong orographic influence in the convective initiation and enhancement. Nevertheless, finer scale studies would certainly prove interesting but would require a denser measurement network and/or a more intensive use of small scale modelling.

\section{Acknowledgments}

The COPS campaign was financially supported by the ANR (grant ANR-06-BLAN-0018-04: COPS/France) and CNRS/INSU (LEFE/IDAO program) in France.

Access to ECMWF operational analyses has been kindly provided in the context of the ECMWF special project "Support Tool for HALO Missions" by Andreas DÖRNBRACK (DLR Oberpfaffenhofen). The authors would also like to acknowledge all the members of the COPS community for the data availability and especially Kersten SCHMIDT (DLR) for the LINET data, Grégoire PIGEON (Météo-France) for the radiosoundings at supersite $\mathrm{V}$, and Franck LAVIE, Olivier GARROUSTE and Francois BOUTTIER (Météo-France) for the UHF wind profiler data. The Satellite-based Nowcasting and Aviation Application Program team from university of Wisconsin-Madison/SSEC provided MSG products, and the DWD provided surface analyses charts. Laurent LABBOUZ would also like to acknowledge Valérian JEWTOUKOFF (LMD) for interesting discussions.

The authors would like to thank the two reviewers for their very interesting and valuable comments which led to a considerable improvement of the manuscript.

\section{References}

Aoshima, F., A. BeHrendt, H.-S. BAUER, V. WulfMeYer, 2008: Statistics of convection initiation by use of Meteosat rapid scan data during the Convective and Orographicallyinduced Precipitation Study (COPS). - Meteorol. Z. 17, 921-930. doi:10.1127/0941-2948/2008/0337.
ASKNE, J., H. NORDIUS, 1987: Estimation of tropospheric delay for microwaves from surface weather data. - Radio Sci. 22, 379-386. doi:10.1029/RS022i003p00379.

BANACOS, P.C., D.M. SCHULTZ, 2005: The Use of Moisture Flux Convergence in Forecasting Convective Initiation: Historical and Operational Perspectives. - Wea. Forecast. 20, 351-366. doi:10.1175/WAF858.1.

BANTA, R., 1990: The role of mountain flows in making clouds. - Atmospheric processes over complex terrain. Meteor. Monogr. 23, 229-282.

Bastin, S., C. Champollion, O. Bock, P. Drobinski, F. MASSON, 2005: On the use of GPS tomography to investigate water vapor variability during a Mistral/sea breeze event in southeastern France. - Geophys. Res. Lett. 32, L05808. doi:10.1029/2004GL021907.

Behrendt, A., S. PAL, F. AOShima, M. BENDER, A. Blyth, U. Corsmeier, J. Cuesta, G. Dick, M. Dorninger, C. Flamant, P. Di Girolamo, T. Gorgas, Y. HuANG, N. KALTHOFF, S. KHODAYAR, H. MANNSTEIN, K. TRÄUMNER, A. WIESER, V. WULFMEYER, 2011: Observation of convection initiation processes with a suite of state-of-theart research instruments during COPS IOP 8b. - Quart. J. Roy. Meteor. Soc. 137, 81-100. doi:10.1002/qj.758.

BENDER, M., G. DiCK, J. WICKERT, T. SCHMIDT, S. SONG, G. GENDT, M. GE, M. RothACHER, 2008: Validation of GPS slant delays using water vapour radiometers and weather models. - Meteorol. Z. 17, 807-812. doi:10.1127/ 0941-2948/2008/0341.

BETZ, H.D., K. SCHMIDT, P. LAROCHE, P. BLANCHET, W.P. OetTinger, E. Defer, Z. DZIEWIT, J. KonARSKI, 2009: LINET-An international lightning detection network in Europe. - Atmos. Res. 91, 564-573. doi:10.1016/ j.atmosres.2008.06.012.

Bevis, M., S. Businger, T. Herring, C. Rocken, R. ANTHES, R. WARE, 1992: GPS meteorology- Remote sensing of atmospheric water vapor using the Global Positioning System. - J. Geophys. Res. 97, 15787-15801.

BI, Y., J. MAO, C. LI, 2006: Preliminary results of 4-D water vapor tomography in the troposphere using GPS. Advanc. Atmos. Sci. 23, 551-560. doi:10.1007/s00376006-0551-y.

BiCA, B., S. SCHNEIDER, S. TSCHANNETT, M. DORNINGER, M. RATHEISER, R. STEINACKER, 2005: high resolution analysis and nowcasting over complex terrain by using physical a priori knowledge. - Proc. Internationnal Symposium on Nowcasting and Very Short Range Forecasting WSN05, Toulouse, France, www.univie.ac.at/IMG-Wien/ meetings/map_d-phase/abstracts/26-hiresprec-bica.pdf

BiCA, B., T. KNABL, R. SteInACKer, M. RATHEISER, M. DORninger, C. LOTTERANER, S. SCHNEIDER, B. CHIMANI, W. GEPP, S. TSCHANNETT, 2007: Thermally and Dynamically Induced Pressure Features over Complex Terrain from High-Resolution Analyses. - J. Appl. Meteor. Climatol. 46, 50.

Bougeault, P., P. Binder, A. Buzzi, R. Dirks, R.A. Houze, J. Kuettner, R.B. SMith, R. SteinAcKer, H. VOLKERT, 2001: The MAP special observing period. Bull. Amer. Meteor. Soc. 82, 433-462. 
Browning, K.A., A.M. Blyth, P.A. Clark, U. CorsmeIER, C.J. Morcrette, J.L. Agnew, S.P. BAllard, D. BAmber, C. BARThlott, L.J. BenNett, K.M. BeswiCK, M. BitTer, K.E. BozIER, B.J. BrooKs, C.G. Collier, F. DAVies, B. DenY, M.A. DiXon, T. FEuerle, R.M. Forbes, C. GAFFARD, M.D. GRAY, R. HANKERS, T.J. Hewison, N. Kalthoff, S. Khodayar, M. Kohler, C. Kottmeier, S. Kraut, M. KunZ, D.N. LAdD, H.W. LEAN, J. LENFANT, Z. LI, J. MARSHAM, J. MCGREGOR, S.D. MobBS, J. Nicol, E. NORTON, D.J. PARKER, F. PERRY, M. RAMATSCHI, H.M.A. RICKETTS, N.M. Roberts, A. Russell, H. Schulz, E.C. Slack, G. VAughan, J. WAight, D.P. WAREInG, R.J. WATSON, A.R. WEBB, A. WIESER, 2007: The Convective Storm Initiation Project. - Bull. Amer. Meteor. Soc. 88, 1939.

Champollion, C., C. Flamant, O. Bock, F. Masson, D.D. TURNER, T. WECKWERTH, 2009: Mesoscale GPS tomography applied to the 12 June 2002 convective initiation event of IHOP_2002. - Quart. J. Roy. Meteor. Soc. 135, 645-662. doi:10.1002/qj.386.

CLARK, T.L., W.D. HALL, J.L. COEN, 1996: Source Code Documentation for the Clark-Hall Cloud-Scale Model Code Version G3CH01. - NCAR/TN-426+STR, NCAR technical note, NCAR, Boulder, CO, USA, www.csa.com/ partners/viewrecord.php?requester $=$ gs\&collection $=$ TRD\& recid $=$ N9816134AH.

DAVIS, J.L., T.A. HERring, I.I. SHAPIRO, A.E.E. RogERS, G. ELGERED, 1985: Geodesy by radio interferometry: Effects of atmospheric modeling errors on estimates of baseline length. - Radio Sci. 20, 1593-1607. doi:198510.1029/ RS020i006p01593.

DAVIS, J.L., G. ElGERED, A.E. NiELl, C.E. KuehN, 1993: Ground-based measurement of gradients in the "wet" radio refractivity of air. - Radio Sci. 28, 1003-1018. doi:199310.1029/93RS01917.

DeE, D.P., S.M. UpPala, A.J. Simmons, P. Berrisford, P. Poli, S. Kobayashi, U. Andrae, M.A. Balmaseda, G. BAlsamo, P. BAUER, P. BeChtold, A.C.M. BelJAARs, L. VAN DE BERG, J. BIDLOT, N. BORMANN, C. DELSOL, R. Dragani, M. Fuentes, A.J. GeER, L. HAIMBERGER, S.B. HeAly, H. Hersbach, E.V. Hólm, L. IsAKSEN, P. KÅllberG, M. KÖHLER, M. MATRICARDI, A.P. MCNally, B.M. Monge-SAnZ, J.-J. Morcrette, B.-K. Park, C. Peubey, P. DE Rosnay, C. TAVolato, J.-N. THÉPAUT, F. VITART, 2011: The ERA-Interim reanalysis: configuration and performance of the data assimilation system. - Quart. J. Roy. Meteor. Soc. 137, 553-597. doi:10.1002/qj.828.

DENG, Z., M. BENDER, F. Zus, M. Ge, G. DiCK, M. RAMATSCHI, J. WICKERT, U. LÖHNERT, S. SCHÖN, 2011: Validation of tropospheric slant path delays derived from single and dual frequency GPS receivers. - Radio Sci. 46, 11. doi:201110.1029/2011RS004687.

EMARDSON, T.R., H.J.P. DERKS, 2000: On the relation between the wet delay and the integrated precipitable water vapour in the European atmosphere. - Meteor. Appl. 7, 61-68. doi:10.1017/S1350482700001377.
Flores, A., G. Ruffini, A. RIUS, 2000: 4D tropospheric tomography using GPS slant wet delays. - Ann. Geophys. 18, 223-234. doi:10.1007/s00585-000-0223-7.

Flores, A., J.V.-G. DE ARELlanO, L.P. GRADINARSKY, A. RIUS, 2001: Tomography of the lower troposphere using a small dense network of GPS receivers. - IEEE Transactions on Geoscience and Remote Sensing 39, 439-447. doi:10.1109/36.905252.

HAGEN, M., J. VAN BAELEN, E. RICHARD, 2011: Influence of the wind profile on the initiation of convection in mountainous terrain. - Quart. J. Roy. Meteor. Soc. 137, 224-235. doi:10.1002/qj.784.

HitsCHFELD, W., J. BORDAN, 1954: Errors Inherent in the Radar Measurement of Rainfall at Attenuating Wavelengths. - J. Meteor. 11, 58-67. doi:10.1175/15200469(1954)011<0058:EIITRM>2.0.CO;2.

HouzE, R.A., 1993: Cloud Dynamics., Academic Press, 573 pp.

Kalthoff, N., B. Adler, C. BARThlott, U. Corsmeier, S. MobBs, S. CREWEll, K. TRÄUMner, C. KotTMEIER, A. WIESER, V. SMITH, 2009: The impact of convergence zones on the initiation of deep convection: A case study from COPS. - Atmos. Res. 93, 680-694. doi:10.1016/ j.atmosres.2009.02.010.

KENYON, S., J. FACTOR, N. PAVlis, S. HolmeS, 2007: Towards the Next Earth Gravitational Model to Degree 2160: Status and Progress. - AGU Spring Meeting Abstracts 06.

Morland, J., C. MÄTZLER, 2007: Spatial interpolation of GPS integrated water vapour measurements made in the Swiss Alps. - Meteor. Appl. 14, 15-26. doi:10.1002/ met.2.

MUELlER, C.K., J.W. WILSON, N.A. CROOK, 1993: The utility of sounding and mesonet data to nowcast thunderstorm initiation. - Wea. Forecast. 8, 132-146, www.osti.gov/

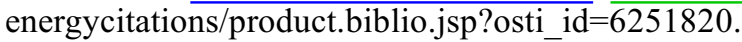

NIELL, A.E., 1996: Global mapping functions for the atmosphere delay at radio wavelengths. - J. Geophys. Res. 101, 3227-3246. doi:199610.1029/95JB03048.

Peters, G., B. Fischer, H. MÜNSTer, M. Clemens, A. WAGNER, 2005: Profiles of Raindrop Size Distributions as Retrieved by Microrain Radars. - J. Appl. Meteor. 44, 1930-1949. doi:10.1175/JAM2316.1.

Planche, C., W. Wobrock, A.I. Flossmann, F. TRIDON, L. LABBOUZ, J. VAN BAELEN, 2013: Small scale topography influence on the formation of threeconvective systems during COPS over the Vosges Mountains. - Meteorol. Z. 22, 395-411. DOI:10.1127/0941-2948/2013/0402.

RALPH, F.M., 1995: Using Radar-Measured Radial Vertical Velocities to Distinguish Precipitation Scattering from Clear-Air Scattering. - J. Atmos. Oceanic Technol. 12, 257-267.

REVERDY, M., 2008: Estimation des paramètres atmosphériques par GPS: analyse de la variabilité spatio-temporelle de la vapeur d'eau. - Université Blaise Pascal, 264 pp.

ReVerdy, M., J. VAN BAElen, A. WALPERsdorf, G. Dick, M. HAGEN, E. RICHARD, 2009: Water vapor fields 
retrieval with tomography software. - Ann. Meteor. 44, 144-145.

Rivas SORIANO, L., F. DE PABLO, 2003: Analysis of convective precipitation in the western Mediterranean Sea through the use of cloud-to-ground lightning. - Atmos. Res. 66, 189-202. doi:10.1016/S0169-8095(02)00160-6.

RoE, G.H., 2005: Orographic Precipitation. - Ann. Rev. Earth Planetary Sci. 33, 645-671. doi:10.1146/ annurev.earth.33.092203.12 $\overline{25} \overline{41 .}$

RotunNO, R., R.A. HouZE, 2007: Lessons on orographic precipitation from the Mesoscale Alpine Programme. Quart. J. Roy. Meteor. Soc. 133, 811-830. doi:10.1002/ qj.67.

SAASTAMOINEN, J., 1972: Introduction to practical computation of astronomical refraction. - Bulletin Géodésique 106, 383-397, doi: 10.1007/BF02522047.

SChroth, A.C., M.S. CHANDRA, P.F. MESICHNER, 1988: A C-Band Coherent Polarimetric Radar for Propagation and Cloud Physics Research. - J. Atmos. Oceanic Technol. 5, 803-822. doi:10.1175/1520-0426(1988) 005<0803: ABCPRF $>2.0 . \mathrm{CO} ; 2$.

SEKO, H., H. NAKAMURA, Y. SHOJI, T. IWABUCHI, 2004: The Meso- $\gamma$ scale Water Vapor Distribution Associated with a Thunderstorm Calculated from a Dense Network of GPS Receivers. - J. Meteor. Soc. Japan 82, 569-586.

Simons, A., S. Uppala, D. DeE, S. Kobayashi, 2007: ERA-Interim: New ECMWF reanalysis products from 1989 onwards. - ECMWF Newsletter 110, 25-35.

SMITH, R.B., 1979: The Influence of Mountains on the Atmosphere. - Advanc. Geophys. 21, 87-230.

SoulA, S., S. CHAUZY, 2001: Some aspects of the correlation between lightning and rain activities in thunderstorms. Atmos. Res. 56, 355-373. doi:10.1016/S0169-8095(00) 00086-7.

STEINACKER, R., C. HÄBERLI, W. PÖTTSCHACHER, 2000: A Transparent Method for the Analysis and Quality Evaluation of Irregularly Distributed and Noisy Observational Data. - Mon. Wea. Rev. 128, 2303-2316. doi:10.1175/ 1520-0493(2000)128<2303:ATMFTA $>2.0 . C O ; 2$.

STEINACKER, R., M. RATHEISER, B. BICA, B. CHIMANI, M. DORNINGER, W. GEPP, C. LOTTERANER, S. SCHNEIDER, S. TSCHANNETT, 2006: A Mesoscale Data Analysis and Downscaling Method over Complex Terrain. - Mon. Wea. Rev. 134, 2758.

TAPIA, A., J.A. SMITH, M. DiXON, 1998: Estimation of Convective Rainfall from Lightning Observations. - J. Appl. Meteorol. 37, 1497-1509. doi:10.1175/1520-0450

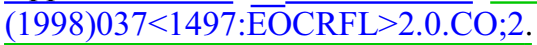

THAYER, G.D., 1974: An improved equation for the radio refractive index of air. - Radio Sci. 9, 803-807. doi:197410.1029/RS009i010p00803.

THIELEN, J., A. GADIAN, 1996: Influence of different wind directions in relation to topography on the outbreak of convection in Northern England. - Annal. Geophysicae 14, 1078-1087. doi:10.1007/s00585-996-1078-3.

THIELEN, J., A. GADIAN, 1997: Influence of topography and urban heat island effects on the outbreak of convective storms under unstable meteorological conditions: a numer- ical study. - Meteor. Appl. 4, 139-149. doi:10.1017/ S1350482797000303.

TRIDON, F., 2011: Mesure des précipitations à l'aide d'un radar en bande $\mathrm{X}$ non cohérent à haute résolution et d'un radar en bande $\mathrm{K}$ à visée verticale. Application à l'étude de la variabilité des précipitations lors de la campagne COPS. Université Blaise Pascal, Clermont-Ferrand, France, $194 \mathrm{pp}$.

Van Baelen, J., Y. Pointin, W. Wobrock, A. Flossmann, G. Peters, F. Tridon, C. Planche, 2009: Precipitation and microphysical studies with a low cost high resolution X-band radar: an innovative project prospective. - Advanc. Geosci. 20, 25-32.

VAn BAelen, J., M. Reverdy, F. Tridon, L. LabBouz, G. DICK, M. BENDER, M. HAGEN, 2011: On the relationship between water vapour field evolution and the life cycle of precipitation systems. - Quart. J. Roy. Meteor. Soc. 137, 204-223. doi:10.1002/qj.785.

Weckwerth, T.M., D.B. PARsons, S.E. KoCH, J.A. Moore, M.A. LeMone, B.B. Demoz, C. Flamant, B. GeERTS, J. WANG, W.F. Feltz, 2004: An Overview of the International H20 Project (IHOP 2002) and Some Preliminary Highlights. - Bull. Amer. Meteor. Soc. 85, 253-277. doi:10.1175/BAMS-85-2-253.

WeCKWERTH, T.M., J.W. Wilson, M. HAGEN, T.J. Emerson, J.O. Pinto, D.L. RifE, L. Grebe, 2011: Radar climatology of the COPS region. - Quart. J. Roy. Meteor. Soc. 137, 31-41. doi:10.1002/qj.747.

Wulfmeyer, V., A. Behrendt, H.-S. BAuer, C. Kottmeier, U. Corsmeier, A. Blyth, G. Craig, U. Schumann, M. Hagen, S. Crewell, P. Di Girolamo, C. Flamant, M. Miller, A. Montani, S. Mobbs, E. Richard, M.W. RotaCH, M. ARPAGAUS, H. RUSSCHENBERG, P. SCHLÜSSEL, M. KÖNIG, V. GÄRTNER, R. StEINACKER, M. DORNINGER, D.D. TURNER, T. WECKWERTH, A. HENSE, C. SIMMER, 2008: RESEARCH CAMPAIGN: The Convective and Orographically Induced Precipitation Study. - Bull. Amer. Meteor. Soc. 89, 14771486. doi:10.1175/2008BAMS2367.1.

Wulfmeyer, V., A. Behrendt, C. KotTMEIER, U. CORSMeIER, C. BARThlotT, G.C. CRAig, M. HAGen, D. Althausen, F. Aoshima, M. Arpagaus, H. Bauer, L. Bennett, A. Blyth, C. Brandau, C. Champollion, S. CRewell, G. Dick, P. Di Girolamo, M. Dorninger, Y. Dufournet, R. Eigenmann, R. Engelmann, C. FlAMANT, T. FOKEN, T. GORGAS, M. GRZESCHIK, J. HANDWERKER, C. HAUCK, H. HÖLLER, W. JUNKERMANN, N. Kalthoff, C. Kiemle, S. KlinK, M. KÖniG, L. Krauss, C.N. Long, F. Madonna, S. MobBs, B. Neininger, S. PAL, G. Peters, G. Pigeon, E. Richard, M.W. Rotach, H. RusschenberG, T. SchWitAlla, V. SMith, R. STEINACKER, J. TRENTMANN, D.D. TURNER, J. VAN BAElen, S. Vogt, H. VOlKert, T. WeCKWERTh, H. Wernli, A. Wieser, M. WIRTH, 2011: The Convective and Orographically-induced Precipitation Study (COPS): the scientific strategy, the field phase, and research highlights. - Quart. J. Roy. Meteor. Soc. 137, 3-30. doi:10.1002/qj.752. 


\section{Appendix: Extraction of SIWV from STD}

The SIWV are obtained from the Slant Wet Delay (SWD), i.e. the specific path delay due to water vapour. The Slant Hydrostatic Delay (SHD) which is the other part of the STD is needed for the calculation. This SHD is obtained from the Zenithal Hydrostatic Delay (ZHD).

Thus, the first step is to calculate the ZHD at each GPS stations. In order to evaluate the ZHD from atmospheric pressure, the classical relationship is used (SAASTAMOINEN, 1972; DAVIS et al., 1985):

$$
Z H D=0.0022768 \frac{P_{0}}{(1-0.00266 \cos (2 \lambda)-0.00028 H)}
$$

where $P_{0}$ is the atmospheric pressure, $H$ is the height above the geoid, and $\lambda$ is the latitude. The latitude, longitude and altitude above the reference ellipsoid (WGS84) are obtained directly from the GPS data processing. This ellipsoidal height is converted into the altitude $\mathrm{H}$ above the geoid (i.e. the geographic height) using the latest version of Earth Gravitational Model, EGM2008 (KENYON et al., 2007). The pressures calculated thanks to VERA are used for all the GPS receivers (because most of the GPS receivers are not collocated with a pressure sensor). VERA gives the mean sea level pressure on an $8 \mathrm{~km}$ grid. Hence a spatial interpolation is made and an altitude correction is applied in order to define atmospheric pressure at each GPS station. The Slant Hydrostatic Delays are obtained by projecting the ZHDs along the corresponding satellite-station paths taking into account Earth curvature (spherical approximation) and pressure gradients (DAVIS et al., 1993; FLORES et al., 2000):

$$
S H D=m_{h} Z H D(1+Z \cot (e))
$$

and:

$$
S W D=S T D-S H D
$$

With $\mathrm{m}_{\mathrm{h}}$ the Niell hydrostatic mapping function (NIELL, 1996), which depends only on the latitude, the altitude, the day of year and the elevation e, and with $Z=\frac{\mathrm{H} \Delta(Z H D)}{\mathrm{ZHD} \Delta \mathrm{s}}$ the normalized delay gradient, where $\triangle(Z H D)$ is the difference between the ZHD at GPS station and the ZHD where the satellite-station ray reaches the altitude $H=\frac{R T}{M g}$ (the scale height of the atmosphere, with $R$ the perfect gas constant, $T$ the absolute temperature, $M$ the mean molecular mass of air, and $g$ the gravitational acceleration) and $\Delta \mathrm{s}$ is the corresponding horizontal distance. Doing so amounts to a first order correction of ZHD spatial variations. This correction is usually negligible but can be quite significant in the presence of strong pressure gradients and/or low ray elevations.

There are mainly two models for SIWV derivation from SWD, the linear model develops by BEVIS et al. (1992), based on comparison between GPS and radiosondes in the US and the polynomial model of EMARDSON and DERKS (2000) for Europe. The two models are different but give very similar results. Surprisingly, the BEVIS et al. (1992) model show better agreement with supersite $\mathrm{V}$ radiosounding data. Hence this model is used for SIWV calculation in the current study:

$$
S I W V=10^{8} \frac{S W D}{\rho R_{v}}\left(\frac{k_{3}}{70.2+0.72 T}+k_{2}^{\prime}\right)^{-1}
$$

with $\mathrm{T}$ the ground level temperature (derived from VERA potential temperature), $\rho$ the density of liquid water, $R_{v}=461.51 \mathrm{~J} \mathrm{~kg}^{-1} \mathrm{~K}^{-1}$ the specific gas constant of water vapour $k_{2}^{\prime}=3.73910^{5} \mathrm{~K}^{2} \mathrm{hPa}^{-1}$ and $k_{3}=22.1 \mathrm{~K} \mathrm{hPa}^{-1}$. The sensitivity of SIWV on ground temperature is quite low: the SIWV variations with temperature are of about $0.25 \%$ per Kelvin. 